Article

\title{
New Allometric Equations to Support Sustainable Plantation Management of Rosewood (Aniba rosaeodora Ducke) in the Central Amazon
}

\author{
Pedro Krainovic $^{1, *}$, Danilo Almeida ${ }^{2}$ and Paulo Sampaio ${ }^{1}$ \\ 1 National Institute of Amazonian Research-INPA, Manaus 69067-001, Brazil; sampaio@inpa.gov.br \\ 2 Forest Sciences Department, University of São Paulo-USP, São Paulo 03178-200, Brazil; \\ daniloflorestas@gmail.com \\ * Correspondence: pedrokrainovic@hotmail.com; Tel.: +55-092-3643-1842
}

Received: 14 June 2017; Accepted: 2 September 2017; Published: 4 September 2017

\begin{abstract}
Rosewood (Aniba rosaeodora Ducke) is an endangered Amazonian tree species which produces one of the most valuable essential oils in the world. The species is used in silvicultural systems which are seen as a means to reducing the pressure of exploitation of natural rosewood populations. There are no specific equations for rosewood plantations, and therefore generalized equations are inappropriate for the species in commercial systems. This study presents allometric equations from 144 trees sampled in different rosewood plantations of Central Amazonia. The equations generated were compared with an equation used in forest management to estimate wood volume and another one recommended by law for rosewood biomass. The equation suggested by current legislation underestimates the actual values by more than $70 \%$ making the viable use of this equation impossible in commercial plantations. The equations generated to estimate the volume and biomass serve as an alternative to the need to develop specific equations for each area and age of the plant. The generic equation for the species is consistent for fresh mass management, with a generalized $R^{2}$ of 0.80 and an underestimation of $0.33 \%$. The equation for crown fresh mass estimation presented a generalized $R^{2}$ of 0.32 and an underestimation of $0.24 \%$. The underestimation of the mass production by rosewood plantations represents a serious impediment to this forest activity. The allometric equations developed are highly applicable under different conditions and management options and should be suggested by the legal provisions regulating rosewood-related activity in Central Amazonia.
\end{abstract}

Keywords: biomass estimation; species conservation; endangered tree; harvest ways; above-ground mass; crown mass; essential oil; non-timber products silviculture; Amazonia

\section{Introduction}

Rosewood (Aniba rosaeodora Ducke, Lauraceae) is an Amazonian tree species that produces an essential oil, in high demand by the world's fine perfumery industry [1,2]. The species was overexploited for decades, which led to its inclusion in the national [3] and international list of endangered species [4,5]. In Brazil, this species is under full protection [6] and current legislation allows for the exploitation of the species only in established plantations. These plantations reduce the pressure on natural populations, generating jobs, income, and promoting development in rural areas. Although recommended by law $[7,8]$, the development of technical criteria for the cultivation and management of this species is still poorly developed.

Biomass quantification is necessary to evaluate biological, economic, and nutrient productivity $[9,10]$. However, the most accurate method for determining biomass is to destructively remove the plant and weigh it. This, especially in the case of trees, is time-consuming, costly, 
and sometimes illegal $[10,11]$. The essential oil yield can vary from $0.75 \%$ to $3.4 \%$ of the distilled biomass [12,13], and above-ground biomass management has been used to extract essential oil from different parts of the plant. Although this method is used, there is no definition of how to estimate the volume and mass of different compartments of rosewood trees in commercial plantations.

Allometrics, in the context of biomass estimation, refers to mathematical equations that consider the relationships between biomass of an entire tree, or its components, to one or more biophysical factors [14,15] and has never been studied in rosewood stands. Furthermore, the use of predictive variables means that equations can be developed to estimate the biomass of branches and leaves [16] for rosewood, and these can be applied to the management of above-ground biomass, adding value to the production chain by the production of "sustainable oil" which can contribute to improving the viability of commercial plantations and to conservation of the species.

The models used to estimate biomass of the trees in the Amazon have produced satisfactory results [9,17-19]. However, analyzing academic results, we verified that the equation suggested by law did not originate from rosewood sampling and is used for several species in several biomes, based on multi-species sampling. The use of this may be inadequate and represents a serious impediment in the subsidy of this forest activity in the Amazon. For this reason, we sampled unique areas of regularized rosewood plantations in Brazil in order to cover the main forms of cultivation and management used today. This sampling represents the largest sampling ever made for the species to date.

There are important sources of uncertainty in above-ground biomass estimates [9,10,20,21], and no allometric equations have been developed specifically for volume and mass estimates in commercial rosewood plantations. Consequently, the aim of the current study is to generate allometric equations to estimate: volume, fresh mass, and dry mass that may be applicable to the management of commercial rosewood plantations helping both management decisions and government actions relating to the use and conservation of the species in Central Amazonia.

\section{Materials and Methods}

\subsection{Descripions of Study Sites}

The study was conducted in two regions of Brazilian Amazonia: Maués and Novo Aripuanã where stands with different ages (the period between the date of tree planting and sampling) were sampled. In the municipality of Maués, two rosewood stands were studied: 10 and 12 years old culture (C 10 and C 12, respectively). In Novo Aripuanã, the study was conducted on one stand, aged 17 years (C 17). Both regions in the state of Amazonas, Brazil (Figure 1), in Central Amazonia [22]. The climate in Maués is hot and humid, with regular and abundant rainfall, and an annual rainfall of $2101 \mathrm{~mm}$ and an annual mean temperature of $27.2^{\circ} \mathrm{C}$, according to Köppen-Geiger, the type climate is Amazonia Af. The soil under rosewood plantations is classified as dystrophic yellow red latosol [23]. The climate of Novo Aripuanã is also classified as type Af, hot and humid according to Köppen-Geiger, with an annual average rainfall of $2444 \mathrm{~mm}$ and an annual mean temperature of $26.9^{\circ} \mathrm{C}$ [24,25]. The soils of the region are predominantly classified as yellow poor latosol saturated by oxidized iron and aluminium with low pH [26] (Table A1-Appendix A of supplementary material for more details).

In Maués, in the 1950s, the natural forest of the region was slash-and-burned to make way for commercial cultivation of guarana (Paullinia cupana Kunth, Sapindaceae), using conventional farming methods. In the 1970s, these plantations were converted to pastures of Brachiaria (Train.) Griseb sp. (Poaceae). Rosewood (Aniba rosaeodora Ducke) plantations only began in the 1990s. Seeds from a variety of different natural populations were used. Once the seedlings were established in the field, a management practice was begun whereby regenerated understory vegetation within the rosewood plantations was annually removed. In this region, 10- and 12-year-old plantations initially planted with different spacings were sampled. New areas for the establishment of rosewood plantations were prepared by cutting and burning the existing vegetation, a method widely used within the Amazon basin [27]. 


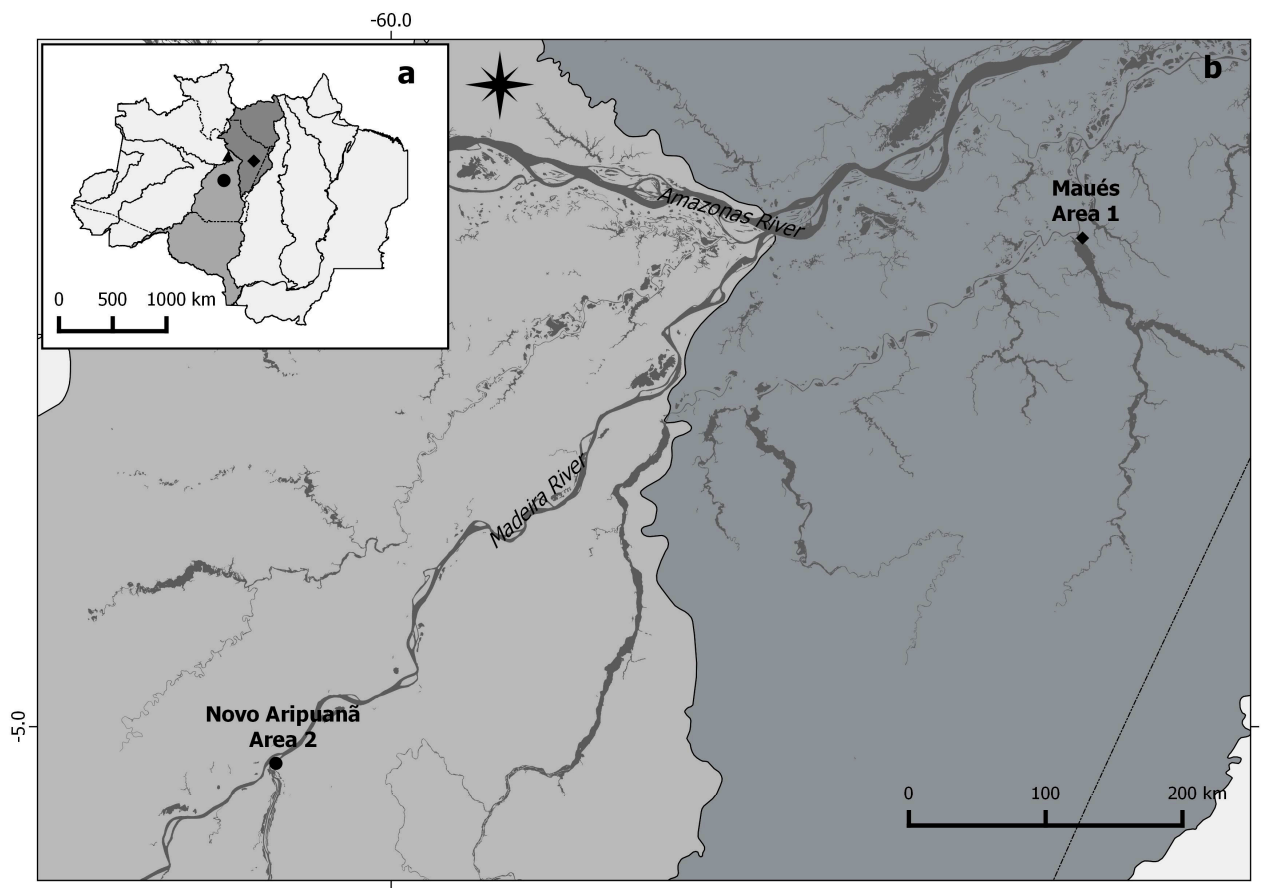

Figure 1. Map of study areas showing (a) Brazilian Legal Amazon, and Amazon River sub-basins; and (b) Maués, directly linked to main Amazon River channel and Novo Aripuanã just inside Madeira River basin.

In Novo Aripuanã, the original forest was cut and burned, then natural regeneration lines were cut in which rosewood seedlings were planted in $5.0 \times 10 \mathrm{~m}$ spacing. The seedlings had been raised from seeds collected from natural populations of the middle Madeira River. After one year in a nursery, the seedlings were taken to the field and planted in the lines traversing the naturally regenerating vegetation. Annual cleaning (removal of vegetation that compete for resources in the planting line) of each planting line was carried out until the 8th year and then again after the 15th year.

\subsection{Data Collection and Sampling}

Field measurements were performed in February and June 2015 in Maués and Novo Aripuanã, respectively. Eight adjacent subplots with six neighbor trees were installed within each cultivated area, distant $25 \mathrm{~m}$ from the edge avoiding any edge effects. Diameter at breast height (DBH-1.30 m above-ground) was measured with a diametric tape and the height of the trees $(\mathrm{H})$ using a 50-meter track (Table A1). The sampled diameters had values between 5.8 and $19 \mathrm{~cm}$, with frequency histogram of tree DBHs following a normal distribution (Shapiro-Wilk normality test, $p=0.586$ for data sets together; $p=0.741$ for $\mathrm{C} 10 ; p=0.735$ for $\mathrm{C} 12$ and $p=0.652$ for $\mathrm{C} 17$ Figure A1).In the three areas, stems of 108 trees were cut at $50 \mathrm{~cm}$ above the ground [7] (Figure A3), and the crowns of 36 trees were pruned with the removal of $100 \%$ of the leaves and branches (Figure A4), totaling 48 trees per area. Fresh trunk and crown masses (here considered as all the leaves and branches that emerge from the main stem, objectified by the harvest) were measured using a digital suspension balance with a capacity of up to $500 \mathrm{~kg}$ and $2 \mathrm{~kg}$ of accuracy (Figure A5).

The mass of the stem and the crown of the trees was measured with a digital suspension scale, previously installed near the collection site. To facilitate mass measurements, the stems of each tree were sectioned using a chainsaw (Figure A6). The sawdust mass and the masses of other remnants were also measured (Figure A6). To determination of the mean water content, discs ( 3 to $6 \mathrm{~cm}$ thick) were collected at points 0,50 , and $100 \%$ of the total height of the commercial stem (Figure A6) and $4 \mathrm{~kg}$ of leaves and branches at the four cardinal points of the middle third of the crown, considering the 
methodological results of Silva, 2007 [19]. The collected samples were weighed in the field with their natural moisture content and then transported to the laboratory where the leaves were oven-dried at $65{ }^{\circ} \mathrm{C}$ until they reached constant mass. For wood samples (branches and discs) the temperature used was $103{ }^{\circ} \mathrm{C}$. Using the mean of water content of the stem and crown, transformation factors of the fresh biomass to dry matter were calculated for each portion, generating a set of data applicable to the allometric model, which uses dry mass estimation.

When the trees had a bifurcation or more than two bole divisions, the diameters of each bole were measured and the average values of transversal area of each bole were calculated. Felled trees (108) were cubed according to the method proposed by [28] that combines the cubing method formulated by Hohenadl, where there is the relative division of the section length, with the Smallian cubing method, which considers the mean basal area and the log length, in which the diameter of the base and top diameters of each section (Figure A2) are measured. The diameter at breast height (DBH), stump diameter (Dstump), and commercial height (Hc) were measured in individuals that had already been felled.

\subsection{Statistical Models and Analyses}

\subsubsection{Development of Allometric Equations of Volume and Biomass}

Based on the previous studies using allometric models in Amazonian forests $[9,17,19]$, those that estimate the volume and fresh and dry masses of the tree and the crown of the trees were selected. Fresh mass estimation is important because fresh mass is what is used for rosewood oil distillation, a method that reduces losses of the volatile constituents of the essential oil. The selected models are based on $\mathrm{DBH}, \mathrm{DBH}$ and height, and as a function of the $\mathrm{DBH}^{2}$ ratio and height (represents basal area).

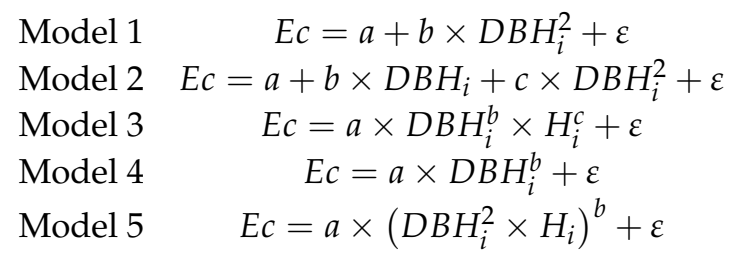

where Ec (Estimated sector) is the volume or mass of a defined compartment (total volume, fresh mass and total above soil dry mass, and the fresh and dry masses of the tree canopies), and parameters a-c are coefficients for each model. Model 1 proposed by Kopesky and Gehrardt; Model 2 proposed by Hohenaldl and Kreen; Model 3 proposed by Shumacher and Hall; Model 4 proposed by Hush and; Model 5 proposed by Spur [29].

The ordinary least squares method was applied for Models 1 and 2 and non-linear least squares method for Models 3-5. In order to determine the best fit model, graphical analysis of percent residual distribution and relative standard error (RSE\%) of observed values on the graphs was estimated for the models, and the degree of adjustment between the observed and estimated values expressed by the AIC index and the adjusted coefficient of determination ( $R^{2}$ adjusted). Additionally, a $t$-test (partial test) was applied for each parameter. For the nonlinear equations, the model was linearized only to obtain the initial coefficients, which were later used for nonlinear estimation. The RSE\%, values for AIC, $R^{2}$ adjusted, and significance of the coefficients for the nonlinear models were calculated following the Gauss-Newton algorithm, using the nonlinear function (nls) for $R$ software [29].

\subsubsection{Comparison between the Models Used}

Three categories were created to compare the models: (1) Species equation: Models tested with all data combined; (2) Area specific equations: Models tested with Maués and Novo Aripuanã data separately; (3) Age-specific equations: Models tested with data from each planting used separately. For each category, the estimated volume, total dry biomass, and total fresh biomass above the soil and crown were calculated. 
Covariance analysis (ANCOVA) was used to evaluate interactions of the predictive variables (DBH and height) with dry and fresh mass and volume, in relation to the categorical variables "age" and "area". When the ANCOVA showed a significant difference for the intercepts or coefficients related to the regression describing the allometry, we applied an analysis of variance (ANOVA) of the residuals of the estimates between the general (for the species) and specific equations (ages, areas). ANCOVA was based on linear or linearized models.

Since there were no specific equations for determining the volume of rosewood in commercial plantations, the general volume calculation equation commonly used in Amazonas state [30] was used for comparisson with the equation suggested in this study. This equation is described by the product between the basal area of the trees and height, multiplied by the form factor (FF) 0.7. The equation suggested by law for calculating the mass of rosewood trees under natural conditions of occurrence (spontaneous environments) was also employed. This equation was developed to be generalist, from the sampling of different tree species. As the law does not state whether this equation is applicable to fresh or dry biomass estimation, it served as a comparison parameter for the equations generated under the two conditions. For each equation, the accuracy with which it estimated absolute values for total mass (as a function of total mass measured in the field) was quantified. Model adjustments were made with the values of RSE\%, AIC, and adjusted $R^{2}$. For the nonlinear models, the generalized $R^{2}$ was used. The comparison between equations was made by contrasting the values estimated from a jacknife (leave-one-out) validation with the sequential withdrawal of an observation, using the values observed and estimated by the contrasted equations. Additionally, the residue distribution plot and observed biplot vs. estimated and the generalized determination coefficient was analyzed. All analyses were performed using $R$ software ( $R$ Foundation for Statistical Computing, Vienna, Austria) [29].

\section{Results and Discussion}

The classes of equations for the prediction of volume and biomass are shown in several ways. As a very large number of equations was generated the values of the coefficients, significance of the coefficients, residues, $R^{2}$, and AIC of all the models used to estimate of volume, dry mass, and fresh mass of each class are presented in the Tables A2-A4.

\subsection{Allometric Models for Volume Estimation}

For the most part, models tested had a better fit at C 12, followed by $C 10$ and C 17, respectively. For all categories, model 3 was chosen to estimate the total volume of rosewood trees in commercial plantations, with significant coefficients, higher values of adjusted $R^{2}$ and lower AIC and RSE\%, values, with emphasis on the separation by areas (area specific equations) and age (age specific equations), which gave the best results (Table A2). ANCOVA revealed no statistical difference in regression coefficients or intercepts between the three area/agea sets (Tables A5 and A6), making it possible to use the equation: $V=0.000071579 D B H^{1.624} \times H^{1.189}$ to estimate the volume, independent of the region or age. The species-specific equations for volume estimation are given in Table 1.

Table 1. Coefficients and statistics of five allometric models (Models 1-5) for estimating Rosewood tree volume ( $n=108$ - category 1$)$ in commercial plantations in Central Amazon. Each coefficient $(\mathrm{a}-\mathrm{c})$ is shown with the standard error in parentheses. The degree of fitness is indicated by percentage of residual standard error (RSE\%), adjusted determination $\left(R^{2}\right)$ coefficient, and Akaike information criterion index (AIC).

\begin{tabular}{lllllll}
\hline Models & $\mathbf{a}$ & $\mathbf{b}$ & $\mathbf{c}$ & RSE\% $^{2}$ & $\boldsymbol{R}^{2}$ & AIC \\
\hline Model 1 & $0.00927( \pm 0.004582)$ & $0.00034( \pm 0.00002492)$ & - & 27.74 & 0.64 & -549.10 \\
Model 2 & $-0.02555( \pm 0.030467)$ & $0.0056( \pm 0.004848)$ & $0.00013 \pm 0.0001876$ & 27.70 & 0.65 & -548.47 \\
Model 3 & $0.000071579( \pm 0.00001661)$ & $1.624( \pm 0.06555)$ & $1.189 \pm 0.06527$ & 13.84 & 0.91 & -698.38 \\
Model 4 & $0.0008837342( \pm 0.0003154)$ & $1.694692783( \pm 0.133663)$ & - & 27.61 & 0.65 & -550.15 \\
Model 5 & $0.00009644673( \pm 0.00002446)$ & $0.8872781( \pm 0.03308)$ & - & 15.43 & 0.89 & -675.86 \\
\hline
\end{tabular}


For greater accuracy, cubing should be performed on the individuals from the inventory area, and represent their characteristics and intrinsic variations [16,31]. When preexisting equations are applied, the precision is less uncertain if a subset of trees is sampled for validation of the equation [32]. However, this step is rarely implemented [10], especially in rosewood plantations of these regions, so that equations that allow a good estimate on different occasions are highly useful tools. This underlies the importance of the results, since they were based on field measurements and did not have significant differences between the variations (age and local), and so can be used in different situations. However, it is possible that new plantations-with significant variation in soil, climate, and silvicultural management-need to develop specific equations.

\subsection{Allometric Models for Estimating Dry Mass}

Combining all data, regardless of age or region (category 1-Table 2), Models 3 and 5 obtained the lowest RSE\% and AIC values.

Table 2. Coefficients and statistics for the five allometric models (Models 1-5) for estimating Rosewood above-ground dry mass (AGDM; kg per tree) ( $n=108$ - category 1$)$ and crown dry mass (CDM; kg per tree) ( $n=144$ - category 1$)$ in commercial plantations in central Amazon. Each coefficient $(\mathrm{a}-\mathrm{c})$ is shown with standard error in parentheses. The level of model fit to the data is indicated by percentage of residual standard error (RSE\%), adjusted determination of coefficient $\left(R^{2}\right)$, and Akaike index (AIC).

\begin{tabular}{|c|c|c|c|c|c|c|}
\hline Models & a & $\mathbf{b}$ & c & RSE $\%$ & $R^{2}$ & AIC \\
\hline \multicolumn{7}{|l|}{ AGDM } \\
\hline Model 1 & $13.08642( \pm 3.66748)$ & $0.26283( \pm 0.01994)$ & - & 26.00 & 0.62 & 894.88 \\
\hline Model 2 & $8.6451( \pm 24.5359)$ & $0.7148( \pm 3.9042)$ & $0.2354( \pm 0.1511)$ & 26.12 & 0.62 & 896.84 \\
\hline Model 3 & $0.14867( \pm 0.0472)$ & $1.50003( \pm 0.09002)$ & $0.93917( \pm 0.1221)$ & 18.92 & 0.80 & 827.21 \\
\hline Model 4 & $1.12( \pm 0.3724)$ & $1.5415( \pm 0.125)$ & - & 26.03 & 0.63 & 895.12 \\
\hline Model 5 & $0.17609( \pm 0.06623)$ & $0.78505( \pm 0.04166)$ & - & 19.13 & 0.80 & 828.53 \\
\hline \multicolumn{7}{|l|}{ CDM } \\
\hline Model 1 & $6.870357( \pm 1.413232)$ & $0.060308( \pm 0.007963)$ & - & 40.72 & 0.28 & 964.32 \\
\hline Model 2 & $12.37413( \pm 9.01858)$ & $-0.90114( \pm 1.45831)$ & $0.095541( \pm 0.05736)$ & 40.81 & 0.28 & 965.94 \\
\hline Model 3 & $0.4507( \pm 0.2553)$ & $1.1659( \pm 0.1598)$ & $0.2965( \pm 0.1757)$ & 40.74 & 0.30 & 965.48 \\
\hline Model 4 & $0.8571( \pm 0.3638)$ & $1.1744( \pm 0.1623)$ & - & 40.99 & 0.29 & 966.23 \\
\hline Model 5 & $0.3358( \pm 0.18043)$ & $0.53527( \pm 0.07173)$ & - & 40.91 & 0.29 & 965.66 \\
\hline
\end{tabular}

The ANCOVA showed a significant difference in the C12 regression for the $\mathrm{DBH}$ variable coefficient ( $p=0.026$; Figure 2-left; Tables A7 and A8). However, the analysis of variance using the species and age-specific equations estimateed for the C12 data set showed a significant difference between the generated residues ( $p=0.0007708$; Figure 2-right; Table A9). This indicates that the generalist allometric equation is not the best equation for $\mathrm{C} 12$. Instead, the suggested equation for use in C 12 is: $A G D M=0.13794 D B H^{1.66283} \times H^{0.74926}$ (Table A3). Separating the data set by sampling site (category 2), Model 5 gave better results for the two regions, although these were very close to Model 3. In the analysis of category 3, separating the data by age, Model 5 was more accurate (lower values of RSE\%) in C 10 and C 17 with AIC and adjusted $R^{2}$ values very close to Model 3, which proved to be more accurate for the $C 12$ data set.

Nonlinear Models 3, 4, and 5 gave the best results for crown dry mass estimation. In the joint analysis of the data, Model 3 was the most accurate (RSE\% $=40.74$, adjusted $R^{2}=0.30$ and AIC $=965.48$ ). For height variables, ANCOVA revealed no significant differences in the regression coefficient between C17 and C12 ( $p=0.0973$; Table A10) and between C17 and C10 ( $p=0.051986$; Table A11). This was confirmed by analyzing the variance of the generated residues between the species and age specific equations for the data set of $\mathrm{C} 17$ ( $p=0.08433$; Table A12), substituting the use of the general equation: $C D W=0.4507 D B H^{1.1659} \times H^{0.2965}$ independent of the location and age of the plantation to estimate crown dry biomass. The results for the models in classes 2 and 3 are given in Table A3. 

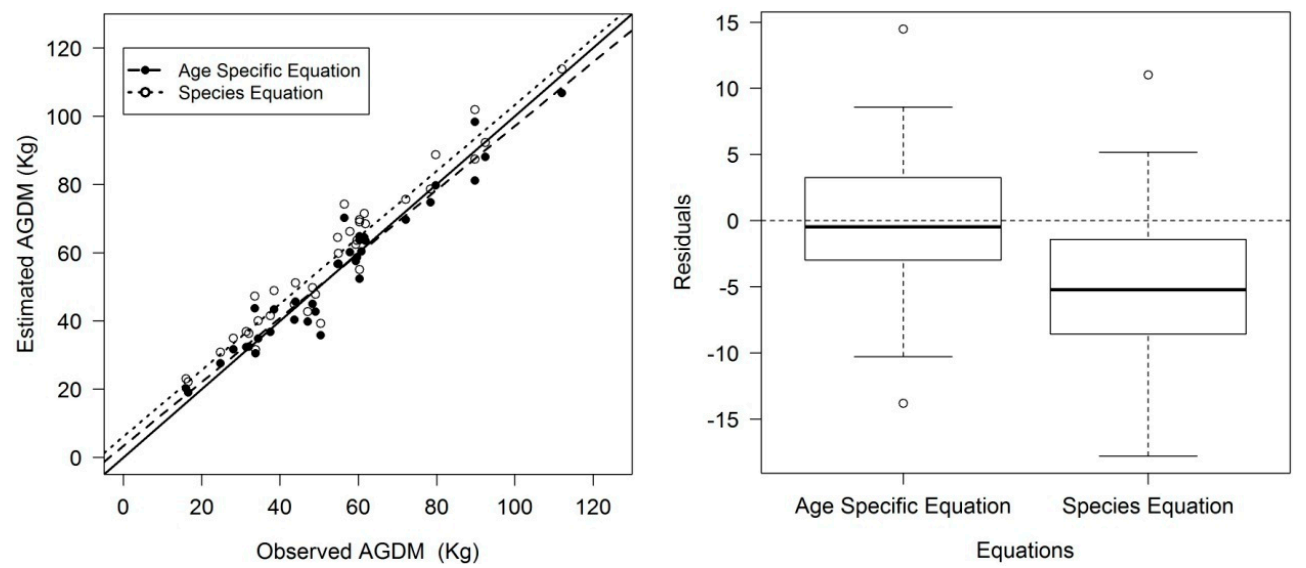

Figure 2. (Left) Comparison of allometric equations of above-ground dry mass (AGDM) using the estimated of "Species Equation" and "Age Specific Equation" for C 12 in relation to the observed values; (Right) Comparing the equations showing the differences between the residuals generated from "Species Equation" and "Age Specific Equation" for AGDM with deviations around the mean.

\subsection{Allometric Models for Fresh Biomass}

Although dry biomass estimates are very common in forest management studies, the material harvested from rosewood plantations is kept in the shade at most for $72 \mathrm{~h}$ prior to the distillation process. This treatment, designed to prevent the excessive loss of volatile materials from the essential oil, makes the application of fresh biomass estimates more appropriate. Model 3 obtained the best results for estimating fresh above-ground biomass (Table 3).

Table 3. Coefficients and statistics of five allometric models (Models 1-5) for estimating rosewood above-ground fresh mass (AGFM; kg per tree; $n=108$ ) and crown fresh mass (CFM; kg per tree; $n=144$ ) in commercial plantations in the Central Amazon. Each coefficient $(a-c)$ is shown with standard error in parentheses. The degree of fitness is indicated by percentage of residual standard error (RSE\%), adjusted determination of coefficient $\left(R^{2}\right)$, and Akaike index (AIC).

\begin{tabular}{|c|c|c|c|c|c|c|}
\hline Models & a & $\mathbf{b}$ & c & RSE $\%$ & $R^{2}$ & AIC \\
\hline \multicolumn{7}{|l|}{ AGFM } \\
\hline Model 1 & $12.71452( \pm 5.6557)$ & $0.45218( \pm 0.02872)$ & - & 17.40 & 0.78 & 983.92 \\
\hline Model 2 & $5.9292( \pm 37.03262)$ & $2.1841( \pm 5.8933)$ & $0.3686( \pm 0.2281)$ & 23.63 & 0.68 & 985.78 \\
\hline Model 3 & $0.31046( \pm 0.09485)$ & $1.54806( \pm 0.08716)$ & $0.78635( \pm 0.08891)$ & 18.21 & 0.81 & 929.46 \\
\hline Model 4 & $1.6607( \pm 0.5011)$ & $1.5872( \pm 0.1133)$ & - & 23.52 & 0.69 & 983.84 \\
\hline Model 5 & $0.319( \pm 0.09231)$ & $0.77631( \pm 0.03854)$ & - & 18.12 & 0.81 & 927.48 \\
\hline \multicolumn{7}{|l|}{ CFM } \\
\hline Model 1 & $10.22513( \pm 2.22657)$ & $0.11251( \pm 0.01255)$ & - & 37.51 & 0.36 & 1095.25 \\
\hline Model 2 & $14.94215( \pm 14.22244)$ & $-0.77233( \pm 2.29977)$ & $0.14259( \pm 0.09046)$ & 37.63 & 0.36 & 1097.14 \\
\hline Model 3 & $0.94096( \pm 0.49099)$ & $1.28087( \pm 0.15078)$ & $0.07649( \pm 0.16372)$ & 37.81 & 0.37 & 1098.48 \\
\hline Model 4 & $1.107( \pm 0.4369)$ & $1.2843( \pm 0.1504)$ & - & 37.70 & 0.36 & 1096.69 \\
\hline Model 5 & $0.53792( \pm 0.27526)$ & $0.54422( \pm 0.06828)$ & - & 38.93 & 0.32 & 1105.94 \\
\hline
\end{tabular}

There was no significant difference between estimates generated by Models 3 and 5 ( $p=0.9033$ ), therefore, Model 3 was chosen to estimate fresh biomass of the species in commercial plantations. The ANCOVA comparison showed a significant difference in the DBH-related regression coefficient between C12 and C10 ( $p=0.02857$; Table A13), while C12 and C10 did not differ from C17 ( $p=0.9061$ and $p=0.58522$, respectively; Tables A13 and A14). Consequently, an analysis of the variance of the residues was performed using the species and age-specific equations for data sets C12 and C10. For C12 the difference was significant ( $p=0.001158$, Figure 3; Table A15), while there was no significant difference between the residues generated and C10 ( $p=0.2644$; Table A16). 

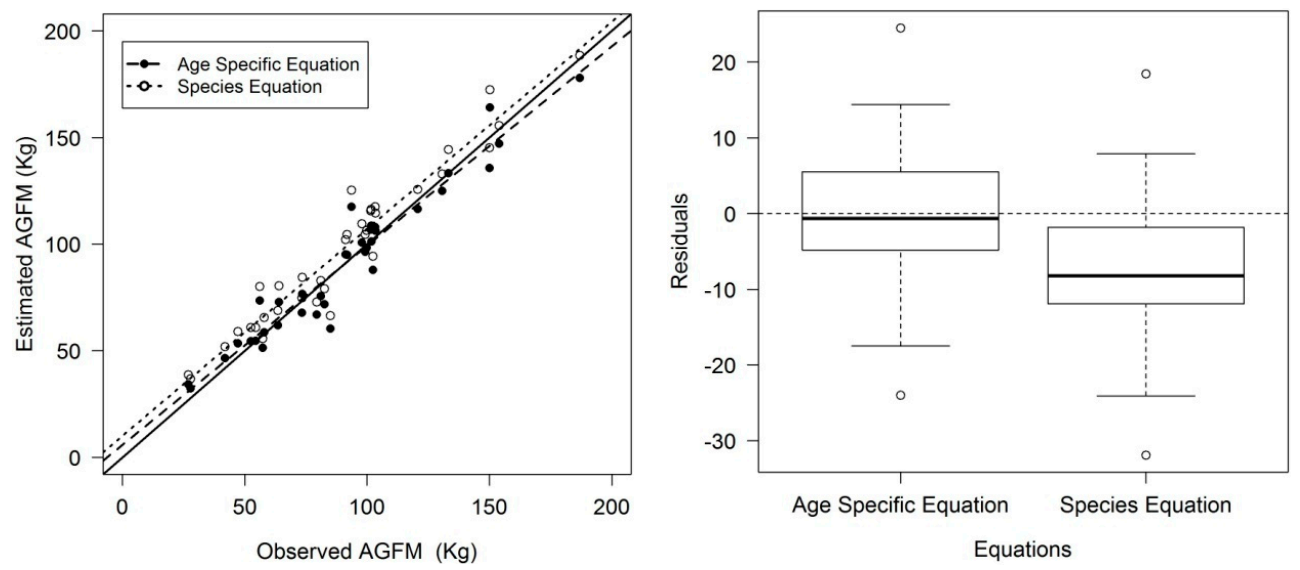

Figure 3. (Left) Comparison of allometric equations of above-ground fresh mass (AGFM) using the estimated values by "Species Equation" and "Age Specific Equation" for C 12 in relation to the observed values. (Right) Comparing the equations showing the differences between the residuals generated from "Species Equation" and "Age Specific Equation" for AGFM with deviations around the mean.

Using the data from the Maués region (C 10 and C 12 combined), Model 3 performed best when adjusted with lower AIC and RSE\% values and higher $R^{2}$ value (0.84) (Table A4). Model 5 showed better adjustments for fresh above-ground biomass for $C 10$ and $C 17$, while Model 3 gave better results for C 12 .

Although the average contribution of fresh stem biomass of all trees weighed directly in this study $(59.08 \%)$ is similar to the value found by Nogueira [33] in open forest (57.9\%), the result reveals that the silvicultural treatments used in C12 changed the allometry of individual trees, requiring the use of a differentiated equation to estimate fresh biomass, so ratifying the results found for dry biomass. The application of species equation to the $\mathrm{C} 12$ data set resulted in an $8.38 \%$ overestimation, against a $4.86 \%$ underestimation generated by the application of age specific equation, which confirms the allometric difference of the $\mathrm{C} 12$ trees being the equation $A G F M=0.24537 D B H^{1.64861} \times H^{0.073956}$ indicated for the estimation of fresh biomass at this site.

For fresh crown biomass, the ANCOVA revealed no differences between C17 and C10 ( $p=0.051986$; Table A17), and between C17 and C12 ( $p=0.0973$; Figure 4-left; Table A18) in the height- related coefficient. Even so, due to the level of significance, we performed ANOVA between the species and age-specific equation for the $\mathrm{C} 17$ dataset and it did not show a significant difference ( $p=0.1921$, Figure 4-right; Table A19) among the generated residues, indicating that the general equation can be used regardless of age and area for the estimation of fresh crown biomass. The equation indicated in this study to estimate fresh crown biomass (CFM) in commercial plantations is $C F M=0.94096 D B H^{1.28087} \times H^{0.07649}$.

Allometric models for estimating CFM have rarely been developed for Amazonian forests [33] and have never been developed for commercial plantations in central Amazonia. The accuracy founded in the present work represented by $R^{2}$ and AIC values, was considered weak when compared to other works [33,34]. However, in the study by Nogueira et al. [33], a mass expansion factor was used, not a direct in-field measurement of crown biomass. For Figueiredo et al. [34] while the data contained crown morphometric variables, the estimate was made using LIDAR technology. In the first case, the allometric equations developed to estimate dry crown biomass were from open forest in the southern Amazon, were adjusted to Model 4 (tested in the present study), with $R^{2}$ adjusted $=0.901$ with a sample of 206 trees of different species [33]. The results indicate that a better application can be found for estimating the CFM of rosewood in commercial plantations. This is usually done with the inclusion of variables of the tree component (crown) inside the models [35]. 

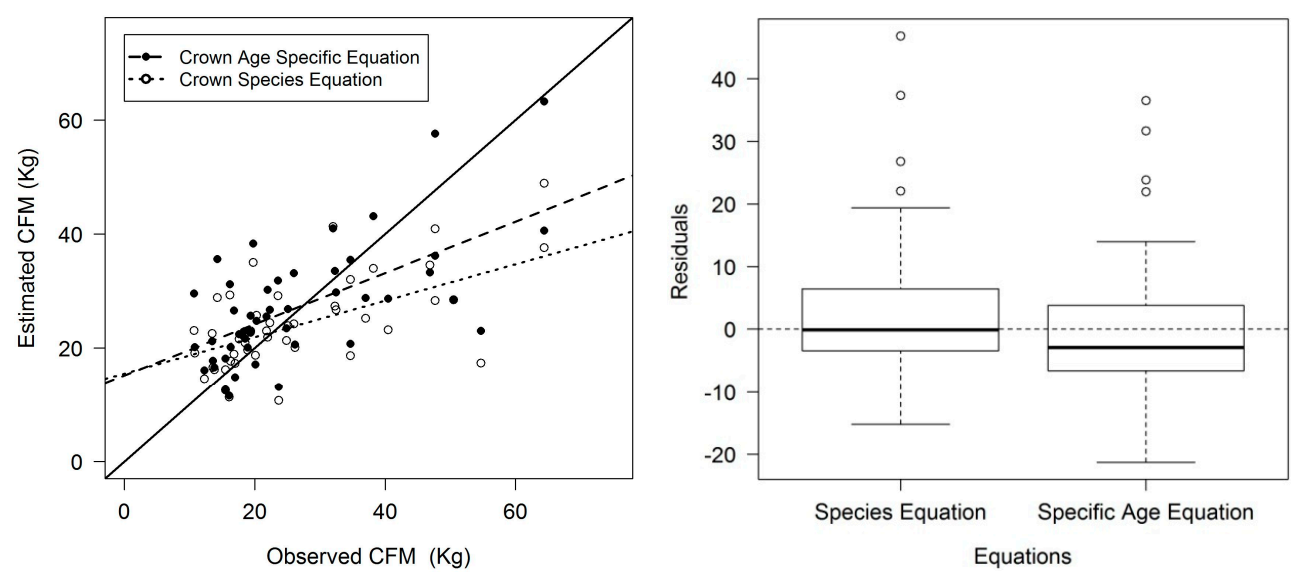

Figure 4. (Left) Comparison of allometric equations of crown fresh mass (CFM) using the estimated values by "Crown Species Equation" and "Crown Age Specific Equation" for C 17 in relation to the observed values. (Right) Comparing the equations showing the proximity of the means of the residues and the overlap of deviations around the mean between "Crown Species Equation" and "Crown Age Specific Equation" for CFM.

On average, rosewood tree fresh crown biomass contributed $40.92 \%$ of the total fresh above the ground biomass. This value becomes $30.19 \%$ when the comparison is based on dry biomass, due to the higher moisture content of the crown tissues, such as leaves and thin branches. There are, however, differences between the study sites in the contribution of the crown to total biomass; with the crowns of Novo Aripuanã trees making, on average, a greater contribution than those from Maués. The results from Maués agree with those from trees weighed directly in the natural forest studied by Nogueira et al. [33] (39.4\%), but they contradict his observation that crowns studied by him in open forests were smaller than those in dense forest. However, this was recorded at Novo Aripuanã, where trees shaded by natural vegetation had larger crowns than those at Maués, which grew in full sun.

The silvicultural method of enriching natural regeneration resulted in a greater proportion of tree biomass being stored in the crowns (proportion of the total weight and weight of the crown). The difference in the crown allometry between sites is probably because of different crown-understory light gradients, which result in differentiation of resource allocation between vertical and horizontal growth between southern and central Amazonia regions [36]. That plantation trees have smaller crowns occurs because, in environments where different species compete, trees can occupy more crown space without mechanical abrasion or penetration by neighboring canopies, and so generate larger canopies than trees in more homogeneous environments [37]. Competition for position in the vegetation column stimulates branch formation and height gain [38]. Depending on the genotype, environment, and age of the plant, this can also impact apical dominance and lateral organ growth, while the leaf area of the plant is strongly related to light attenuation $[38,39]$.

Peer et al. [35], studying competition effects on the architecture of commercial tree species, noted that some species increase the H/D ratio, decreasing crown branching to reach the upper crown, while others (like rosewood) are more shade tolerant, and show increased branching to capture light, optimizing photosynthesis. In the case of competitive monocultures, the extent of crown branching is smaller, and the plasticity of the architecture is influenced by the strategy avoiding or tolerating overlap-induced shapding [40]. Thus, crown height and size in C17 is likely to be influenced by competition for light.

In general, rosewood has an architectural model consisting of a monopodial orthotropic main axis, (Figure A7), with variation due to bifurcations. Its architecture in natural forest is described as tall with a small or narrow crown [41-43]. However, in the homogeneous plantations of Maués, as well as in the enrichment lines at Novo Aripuanã, tree architectures were variable enough that such a classification was not possible. This was probably due to competition between trees in plantations influencing 
the indivudual architecture before and during crown closure [35]. In 37-year-old plantations at the Adolpho Ducke Forest Reserve, Manaus, Brazil, the biomass distribution of a rosewood tree was described as consisting of $86.2 \%$ trunk, $6.17 \%$ branches, and $7.63 \%$ leaves $[44,45]$. However, at the time, the trees occupied the upper crown position in relation to the adjacent forest, and so had lower crown plasticity [37]. In contrast, current legislative definitions attribute a $34.4 \%$ contribution of crown to the total mass of the tree under natural conditions, which, instead, is close to the value found in the present study for relatively young commercial plantations.

In general, the models gave the most accurate results with C 12 (Tables A2-A4), especially in terms of the lower amplitude of residues for evaluated parameters. In plots, the trees had initially been planted more densely, so that the morphology or ecophysiological characteristics observed may be related to competition, rather than to plant size or biomass [38]. Life history strategies [10], climate [20], and site characteristics [46] contribute significantly to variation in above-ground biomass, making it necessary to understand dynamics of growth of this species under various cultivation patterns so that production can be managed appropriately. This is a relevant topic for later studies.

DeMalach et al. [47] describe the Tilman-Grime debate in which the effects of competition can be separated into two groups: (1) where competitive capability causes competitors to overcome suppression by neighbors and grow faster [48]; and (2) when individuals survive longer with low levels of resources [49]. As a result of competition for spaces, water, light, and nutrients a higher or lower density of plants can generate dierent productive behavior responses [39]. An increase in vegetative production may give a competitive advantage [48]. The continuous spacing of C 10 resulted in a higher stock biomass, probably due to the reduction in self-shading and the consequent delay of competition for soil resources, leading to a high efficiency in the capture and use of resources [39]. Plants without close neighbors are usually larger and have different morphology/architecture than those with many neighbors [37] explaining the allometry seen in C12, where the smaller spacing in the early planting years may have resulted in a greater similarity in tree allometry, without suppression of one individual over the other due to competition, a common mechanism in homogeneous environments.

The height parameter $(\mathrm{H})$ is not always incluced in allometric models as it can be difficult to measure in the field [50]. This could, potentially, cast doubt on the validityof the models developed here. However, in forest plantations this measurement can be made more accurately than in the wild. In addition, if the total height of the tree is available, the allometric model is far less biased [51] and more accurate estimates result [52]. Therefore, the relatively high RSE\% values of Models 1, 2, and 4 were attributed to the inclusion of the $\mathrm{H}$ parameter in Models 3 and 5. Adjusted $R^{2}$ and AIC are adjustment measures that penalize the addition of parameters to models [11]. However, the inclusion of the height parameter appears to have improved the model, as indicated by the non-significant hypsometric relation in the data set $(p=0.797)$, which reveals the low correlation between diameter and height of rosewood trees in commercial plantations $\left(R^{2}=0\right)$, making the inclusion of the $\mathrm{H}$ parameter in the models significant.

Model 4, although exponential, does not include the parameter $H$. Instead, it was an intermediate model between those using single and double linear DBH input (Models 1 and 2) and exponential models that included parameter $\mathrm{H}$ (Models 3 and 5). Accuracy of the models followed this order: Model $2<$ Model $1<$ Model $4<$ Model $5<$ Model 3. This order was maintained for regional variations of our sampling, which has been widely reported in the literature [16,33,51-53]. The models tested in the two regions of Central Amazonia did not differ, even the areas that had distinct edaphoclimatic conditions, which could be explained by the remarkable plasticity in response to the environmental conditions that trees possess [35].

\subsection{Comparison of the Developed Equations with Preexisting Equations}

Table 4 summarizes the equations from the allometric models tested and chosen to estimate the volume and the dry and fresh biomass of the entire tree and crown, in addition to the general equations of volume estimation and the equation suggested by law for estimating tree biomass of rosewood in natural forests. 
Table 4. Allometric models developed for rosewood commercial plantations at different tree sample-plots for estimating volume tree $\left(\mathrm{V}-\mathrm{m}^{3}\right.$ per tree), above-ground dry mass (AGDM; $\mathrm{kg}$ per tree), above-ground fresh mass (AGFM; kg per tree), crown dry mass (CDM; kg per tree), and crown fresh mass (CFM; kg per tree) with stem diameter at breast height $\mathrm{DBH}(\mathrm{cm})$ and height $(\mathrm{m})$ in contrast with allometric models used in Amazon for estimating volume and equations by normative instruction (NI) for estimating rosewood biomass. The allometric equations were developed on the basis of two regions from Central Amazonia with 108 trees for volume and total weight and 144 trees for crown mass.

\begin{tabular}{|c|c|c|}
\hline Models & Equations & Source \\
\hline \multicolumn{3}{|l|}{ Volume } \\
\hline Model 3 & $V=0.000071579 D B H^{1.624} \times H^{1.189}$ & This study \\
\hline Generalist model & $V=\left(\left(\pi \times D A P^{2} / 40000\right) \times H\right) \times 0.7$ & Used in Amazon \\
\hline \multicolumn{3}{|l|}{ AGDM } \\
\hline Model 3 & $A G D M=0.14867 D B H^{1.50003} \times H^{0.93917}$ & This study \\
\hline By law & $A G D M=0,0009 D B H^{1.585} \times H^{2.651}$ & NI Nº9/2011 \\
\hline \multicolumn{3}{|l|}{ CDM } \\
\hline Model 3 & $C D M=0.4507 D B H^{1.1659} \times H^{0.2965}$ & This study \\
\hline By law & $C D M=0,0009 D B H^{1.585} \times H^{2.651} \times$ canopy $(0.344)$ & NI N ${ }^{\circ} 09 / 2011$ \\
\hline \multicolumn{3}{|l|}{ AGFM } \\
\hline Model 3 & $A G F M=0.31046 D B H^{1.54806} \times H^{0.78635}$ & This study \\
\hline By law & $A G F M=0,0009 D B H^{1.585} \times H^{2.651}$ & NI N ${ }^{\circ} 09 / 2011$ \\
\hline \multicolumn{3}{|l|}{ CFM } \\
\hline Model 3 & $C F M=0.94096 D B H^{1.28087} \times H^{0.07649}$ & This study \\
\hline By law & $C F M=0,0009 D B H^{1.585} \times H^{2.651} \times$ canopy $(0.344)$ & NI Nº9/2011 \\
\hline
\end{tabular}

Once the best models were chosen, the equations generated to calculate the values of the estimated variables of interest were used. Equations developed in this study for volume estimation were compared to the general volume estimation used in the Brazilian Amazon (Figure 5-Left). The sum of the estimates calculated by the Jacknife method gave an overestimation of $0.15 \%$ due to the compensation for the over- and under-estimation, while the general equation for volume calculation overestimated the observed values by $32.79 \%$, what is seen in the residues distribution (Figure 5-Right). The average tapering (form factor) adopted for the general equation is derived from measurements of trees with bark and circumference $\geq 100 \mathrm{~cm}$, including all species, regardless of forest type, diameter class, or stem length [33,54].
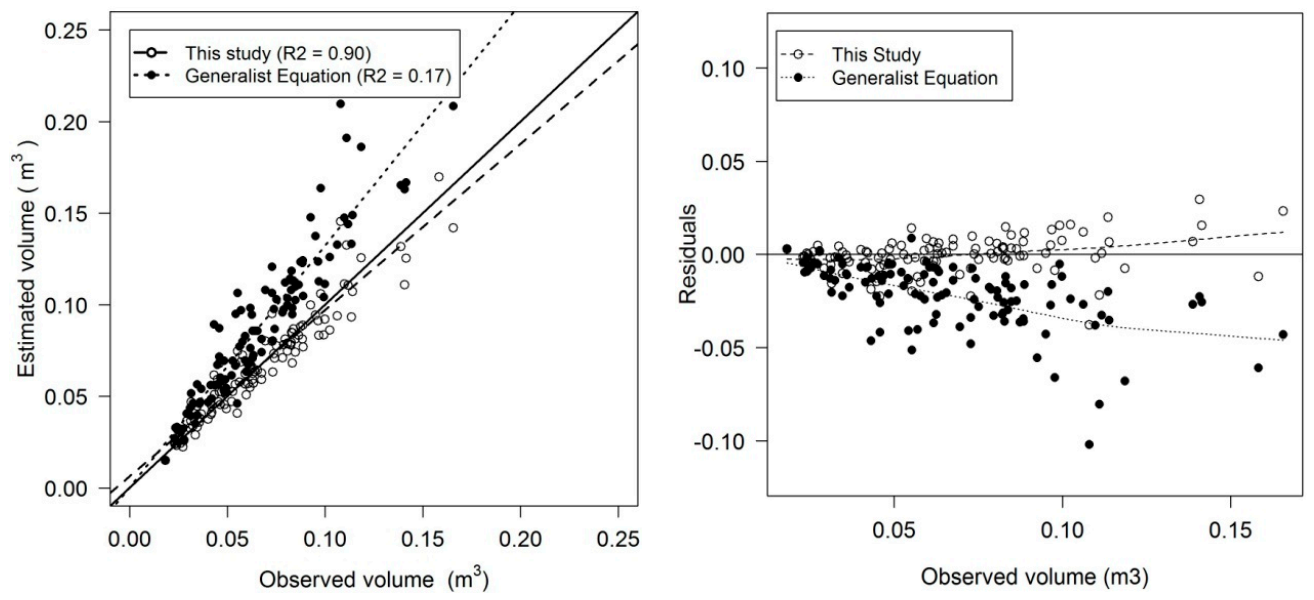

Figure 5. (Left) Comparison of allometric equations of volume using the values estimated by "Species Equation" and "Generalist Equation" used in the Amazon in relation to the values observed in rosewood plantations in the study sites and; (Right) Comparison of allometric equations of volume using residues distribution . 
Nogueira et al. [33] attributes the major sources of uncertainty in the calculation of wood volume in the Amazon to the use of a single form factor for trees of all sizes and in all types of forests. However, when studying the general model of volume estimation, the same author reported that form factor value is 0.709 for dense forests of central Amazonia and 0.76 for open forests, and concluded that no adjustments are necessary in the form factor used in the general model (0.7). However, for the volume of rosewood cultivated in commercial plantation, we found the general model overestimated in comparison to observed values, and the average FF value for the current study was 0.54 . This can be explained by the size and shape of the crown characteristic of the species and the relation of the trees to the water and fertility conditions of the environments [11]. In addition, regular spacing of trees within plantations both favors growth and is a cause tree shapes that differ from those in the wild $[33,37-39,47,48]$

For AGFM, the equation legally suggested by the normative instruction, gave an estimate that was only $23.5 \%$ of the total AGFM, an underestimation of $76.5 \%$, tending to higher under-estimates for larger trees (Figure 6-Left). The application of equation generated in this study did not result in bias or systematic errors, while the equation suggested by law systematically underestimates all trees (Figure 6-Right). Although this occurs, the sum of the estimates calculated by the jacknife method for Model 3 was similar to those obtained in the field (10,370.3 $\mathrm{kg}$ and 10,339.94 $\mathrm{kg}$ respectively), with an underestimation of $0.33 \%$ due to the over- and underestimation compensations for all sizes of trees.
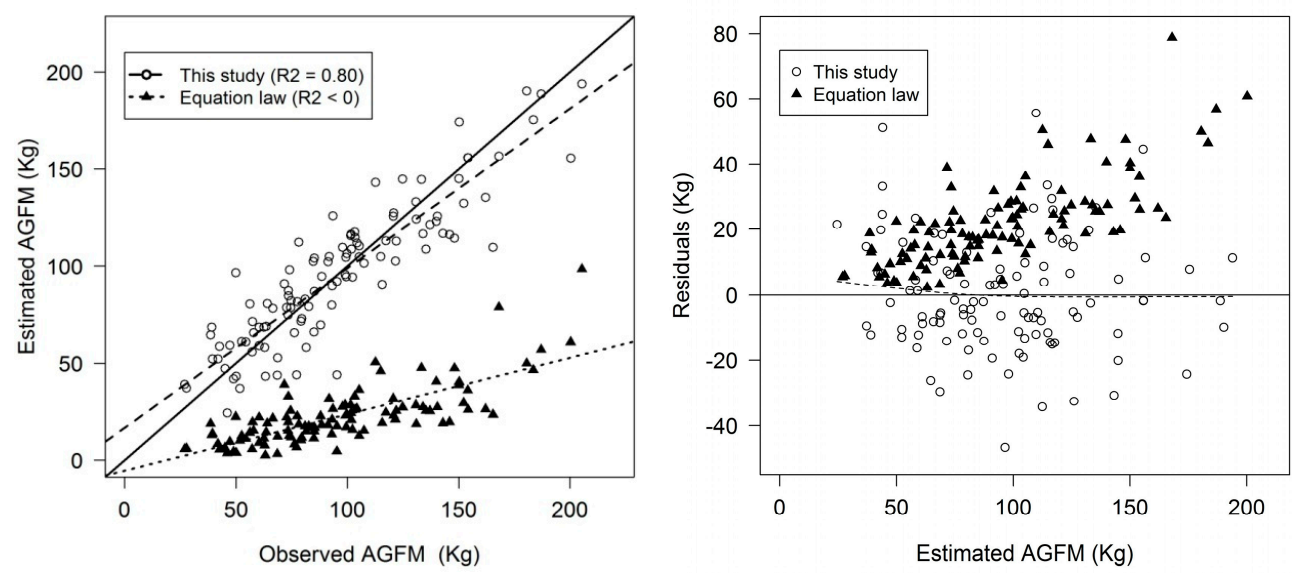

Figure 6. (Left) Comparison between above-ground fresh mass (AGFM) equation developed in this study and law-based equation currently recommended by estimated and observed plot and; (Right) Residuals distribution of the two allometric equations for AGFM estimation.

For CFM, The equation suggested by the Brazilian law for crown mass, estimates only $25.81 \%$ of the mass observed, an underestimation of $74.19 \%$ (Figure 7-Left), systematically sub-estimating all trees (Figure 7-Right). The distribution of the residuals of the equation generated in this study for CFM show sub- and over-estimates of all sizes of trees, which resulted in an underestimation of $0.24 \%$ in relation to the observed total. It is important to note that the crown's contribution to the total mass of the tree was obtained from the law, but the fact that there is no equation constructed specifically for estimating CFM makes this result even more important due to its application and novelty.

Today, the activity is controlled by the volume of essential oil exported, controlled by the Ministry of Development, Industry and Foreign Trade. With the volume of exported oil related to biomass underestimated by the equation now suggested by law, the yield (quantity of essential oil in relation to mass) is erroneously high, since the amount of essential oil is obtained from a mass that is highly underestimated. This situation allows plantings to have few trees felled in the plantation, while most of the mass needed to obtain that volume of oil quantified on export could come from natural populations, which is illegal. In other words, productive plantations might reduce their real exploitation, while oil production remains high, supplemented by raw material from natural populations. 

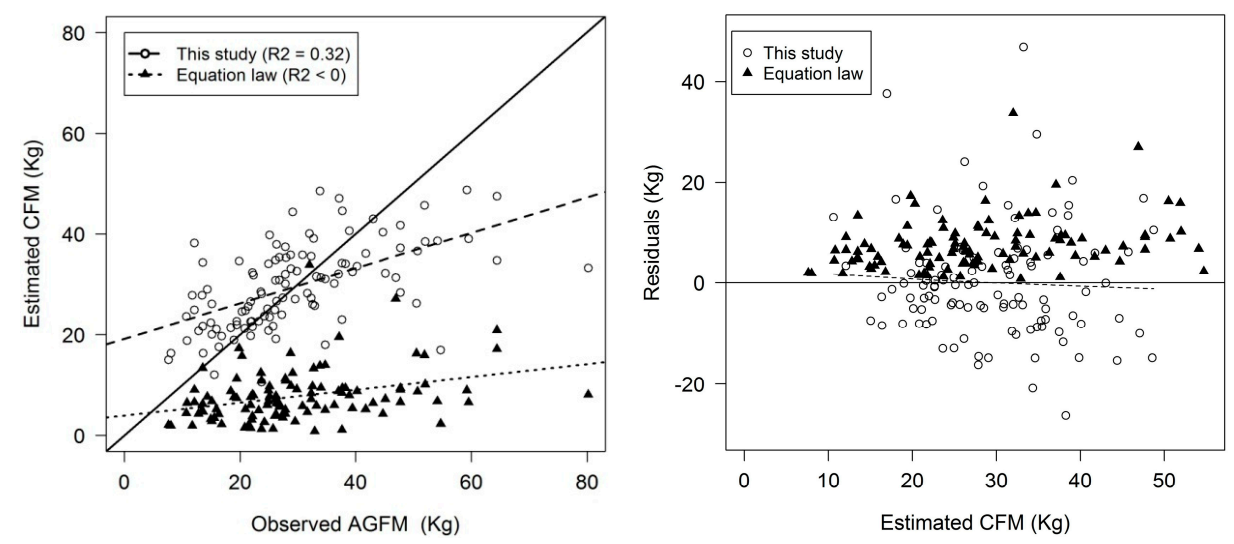

Figure 7. (Left) Comparison between allometric equation of this study and law-based equation for estimating rosewood crown fresh mass (CFM) and; (Right) Residuals distribution of the two allometric equations for CFM estimation.

In addition, it is important to point out that the allometric equations developed contribute to carbon stock assessment [55], introducing rosewood cultivation among land-use change options that generate revenues from the conservation of forest carbon stocks [56]. Plantation forestry is among the options for mitigation of deforestation and carbon emissions proposed for the Amazon [46,57-59]. The carbon outflows are associated with deforestation by agriculture, timber commercial exploitation, and soil oxidation, while the entrance is related to reforestation and recovery of forest vegetation [20].

\section{Conclusions}

We conclude that there is encouraging evidence that general predictive equations can be developed across sites in Central Amazonia. The allometric equations developed for estimates of mass and volume can be a good alternative for forest management in productive rosewood plantations under different conditions and management options and should be suggested by the legal provisions regulating rosewood-related activity in Central Amazonia. The compensation between sub- and over-estimation of all sizes of trees indicated that these equations are appropriate to use in forestry operations with some trees and not with individual trees. Equations suggested by law underestimate the mass when applied in rosewood plantations. The incorrect estimation of the real value of the mass and, consequently, of the carbon stored by rosewood plantations, represents a serious impediment in the subsidy of this forest activity in the Amazon, and there is a need to amend the current legislation regarding productive environments. Although the plantations are heterogeneous in terms of the origin of their stock, considerations of the auto ecology of the species indicate that competition for light is a preponderant factor in the architectural development of the crowns and their relative contribution to the total mass of the rosewood trees. In addition, due to the variability of the equations found, climate, soil and silvicultural management can cause specific morphological responses. For this reason, we consider it important that ecological studies of intra-specific competition in different commercial plantations of rosewood should be conducted in order to generate a better understanding of the effect of these variables on tree development.

Acknowledgments: The authors would like to thank FAPEAM-Amazonas Research Foundation for the financial support to carry out the research; Carlos Magaldi, Zanone Magaldi, and Akira Tanaka for granting the study areas; and Adrian Ashton Barnett, a native English speaker who reviewed the spelling and grammar of this manuscript. Additionally Danilo Roberti Alves de Almeida thanks FAPESP-São Paulo Research Foundation (grant 2016/05219-9) for the financial support.

Author Contributions: P.K. collected the experimental data, wrote the manuscript, and did data analysis. All co-authors participated equally in experiment design and manuscript preparation.

Conflicts of Interest: The authors declare no conflict of interest. 


\section{Appendix A}

Table A1. Description of study areas showing values for diameter at breast height (DBH) height (H), above-ground fresh mass (AGFM), percentage of canopy fresh weight, and form factor $(\mathrm{FF}){ }^{*}$ of the trees in farmlands near Maués and Novo Aripuanã, Amazonas, Brazil.

\begin{tabular}{|c|c|c|c|c|c|c|c|c|}
\hline $\begin{array}{l}\text { Soil Management } \\
\text { System }\end{array}$ & $\begin{array}{l}\text { Planted } \\
\text { Date }\end{array}$ & Spacing (m) & AGFM (Kg) & DBH (cm) & $\mathrm{H}(\mathrm{m})$ & $\begin{array}{l}\text { Crown Mass } \\
\text { Proportion (\%) }\end{array}$ & FF & General Description of Cultivated Areas \\
\hline $\begin{array}{l}\text { Rosewood } \\
\text { plantations } \\
\text { (cultivated for } \\
10 \text { years): C10. }\end{array}$ & 2005 & $3.0 \times 4.0$ & $102.47 \pm 33.69$ & $13.88 \pm 2.37$ & $8.15 \pm 1.39$ & $35.89 \pm 6.91 \%$ & $0.49 \pm 0.061$ & $\begin{array}{l}\text { Rosewood seedlings planted following } \\
\text { cutting and burning of original vegetation. } \\
\text { Pure stand. }\end{array}$ \\
\hline $\begin{array}{l}\text { Rosewood } \\
\text { plantations } \\
\text { (cultivated for } \\
12 \text { years): C12. }\end{array}$ & 2003 & $1.5 \times 2.0$ to $3.0 \times 4.0$ & $89.89 \pm 36.44$ & $12.80 \pm 2.68$ & $9.49 \pm 1.13$ & $32.01 \pm 8.06 \%$ & $0.57 \pm 0.053$ & $\begin{array}{l}\text { Rosewood seedlings planted following } \\
\text { cutting and burning of original vegetation. } \\
\text { Pure stand }\end{array}$ \\
\hline $\begin{array}{l}\text { Rosewood } \\
\text { plantations } \\
\text { (cultivated for } \\
\text { 17 years): C17. }\end{array}$ & 1998 & $5.0 \times 10 \mathrm{~m}$ & $96.02 \pm 39.78$ & $12.7 \pm 2.8$ & $11.02 \pm 1.97$ & $54.87 \pm 17.99 \%$ & $0.57 \pm 0.106$ & $\begin{array}{l}\text { Rosewood seedlings planted, following } \\
\text { cutting and burning of original vegetation. } \\
\text { Planting lines were maintained in the } \\
\text { middle of naturally regenerating, } \\
\text { occasionally cut vegetation in the lines. }\end{array}$ \\
\hline
\end{tabular}

* Form factor for each tree was calculated using the ratio of the calculated volume to a volume that assumed the canopy was a perfect cylinder. 

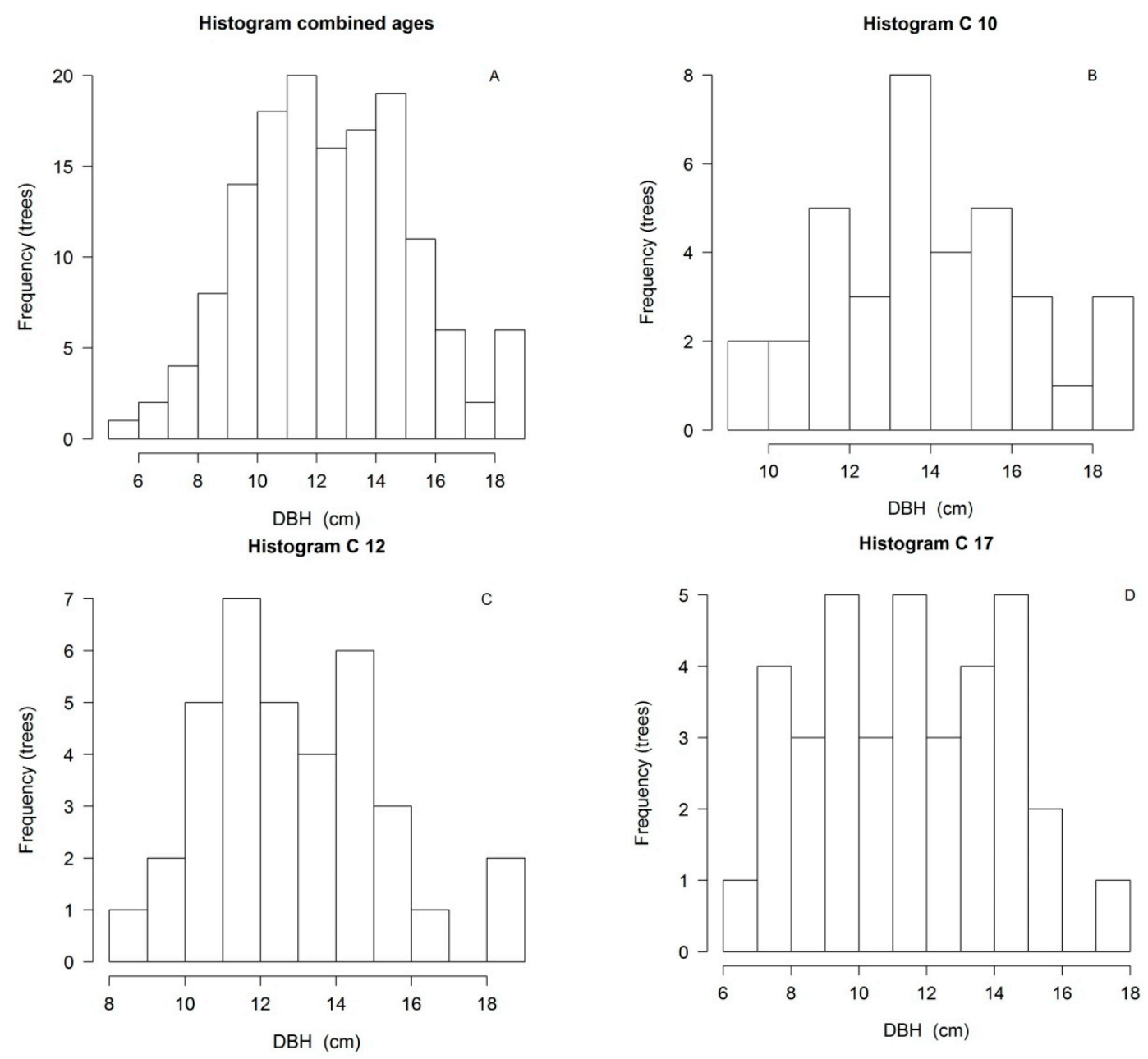

Figure A1. (A) Histogram of DBH frequency of trees in three study sites. $n=144$ - Shapiro-Wilk normality test, $p=0.586$; (B) Histogram of DBH frequency of trees in C 10-Shapiro-Wilk normality test, $p=0.741$; (C) Histogram of DBH frequency of trees in C 12-Shapiro-Wilk normality test, $p=0.735$ and; (D) Histogram of DBH frequency of trees in C 17-Shapiro-Wilk normality test, $p=0.652$.

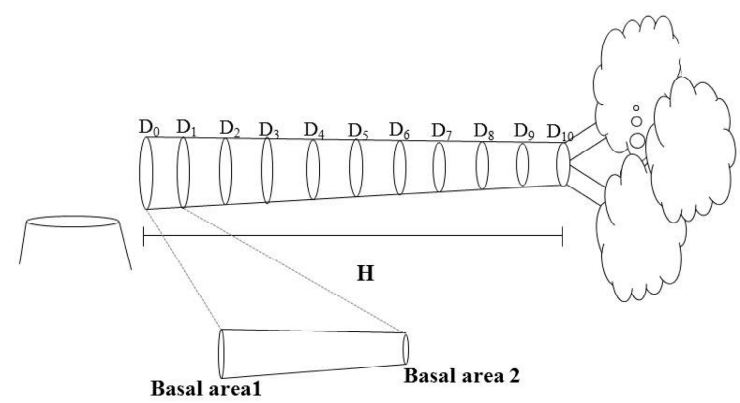

Figure A2. Illustration of the tree cubing method by HOHENALDL (10 sections) and sections by Smalian. 
Table A2. Test results for the five models assayed for tree volume calculation for each category containing parameters calculated for each equation $(a, b$, and $c)$; Significance of the coefficients ( $p$ value); Standard error of the coefficients (std error.); Number of sample trees used to calculate equation ( $n$ ); Residuals (RSE and RSE\%), Coefficient of determination $\left(R^{2}\right)$ and Akaike index (AIC). N.A means Novo Aripuanã.

\begin{tabular}{|c|c|c|c|c|c|c|c|c|c|c|c|c|c|c|c|}
\hline Model & Variation & $a$ & Std. Error $a$ & $p$ Value $a$ & $b$ & Std. Error $b$ & $p$ Value $b$ & $c$ & Std. Error $c$ & $p$ Value $c$ & $n$ & RSE & RSE\% & $R^{2}$ & AIC \\
\hline \multirow{5}{*}{1} & 10 years old & -2.00233 & $6.79 \times 10^{-3}$ & 0.733 & 0.00033 & $3.26 \times 10^{-5}$ & $8.75 \times 10^{-12}$ & - & - & - & 36 & 0.01271 & 20.20 & 0.74 & -208.22 \\
\hline & 12 years old & -0.00184 & $4.64 \times 10^{-3}$ & 0.694 & 0.00044 & $2.51 \times 10^{-5}$ & $2.00 \times 10^{-16}$ & - & - & - & 36 & 0.01048 & 14.45 & 0.90 & -222.08 \\
\hline & $17 /$ N.A & 0.00937 & $7.47 \times 10^{-3}$ & 0.218 & 0.00041 & $4.83 \times 10^{-5}$ & $4.94 \times 10^{-10}$ & - & - & - & 36 & 0.02002 & 30.01 & 0.68 & -175.48 \\
\hline & Combined ages & 0.00927 & $4.58 \times 10^{-3}$ & 0.0457 & 0.00034 & $2.49 \times 10^{-5}$ & $2.20 \times 10^{-16}$ & - & - & - & 108 & 0.01869 & 27.74 & 0.64 & -549.10 \\
\hline & Maués & 0.00192 & $5.29 \times 10^{-3}$ & 0.7118 & 0.00036 & $2.69 \times 10^{-5}$ & $2.00 \times 10^{-16}$ & - & - & - & 72 & 0.01565 & 23.11 & 0.71 & -390.37 \\
\hline \multirow{5}{*}{2} & 10 years old & -0.09322 & 0.0588237 & 0.0765 & 0.01342 & 0.0086273 & 0.0737 & -0.0001518 & 0.000311 & 0.3234 & 36 & 0.01245 & 19.79 & 0.77 & -208.76 \\
\hline & 12 years old & $4.34 \times 10^{-6}$ & $3.47 \times 10^{-2}$ & 0.9999 & $\begin{array}{l}0.0100029 \\
-0.002\end{array}$ & $5.43 \times 10^{-3}$ & 0.9577 & 0.00045 & $2.07 \times 10^{-4}$ & 0.0384 & 36 & 0.10639 & 14.67 & 0.90 & -220.08 \\
\hline & $17 /$ N.A & -0.07829 & 0.0436559 & 0.082 & 0.01492 & 0.0073298 & 0.0499 & -0.00018 & 0.0002976 & 0.5416 & 36 & 0.01916 & 28.71 & 0.72 & -177.74 \\
\hline & Combined ages & -0.02555 & 0.030467 & 0.404 & 0.0056 & 0.004848 & 0.25 & 0.00013 & 0.0001876 & 0.494 & 108 & 0.01867 & 27.70 & 0.65 & -548.46 \\
\hline & Maués & -0.1705 & 0.0411117 & 0.68 & 0.00291 & 0.0062586 & 0.643 & 0.00025 & 0.0002331 & 0.29 & 72 & 0.01574 & 23.24 & 0.72 & -388.59 \\
\hline \multirow{5}{*}{3} & 10 years old & $8.74563 \times 10^{-5}$ & $3.92 \times 10^{-5}$ & $3.25 \times 10^{-2}$ & 1.532782 & $1.54 \times 10^{-1}$ & $1.96 \times 10^{-11}$ & 1.193051 & $1.19 \times 10^{-1}$ & $3.23 \times 10^{-8}$ & 36 & 0.00787 & 11.67 & 0.91 & -241.81 \\
\hline & 12 vears old & $7.19168 \times 10^{-5}$ & $2.45 \times 10^{-5}$ & 0.00601 & $\begin{array}{l}1.03702 \\
1.76018\end{array}$ & $9.20 \times 10^{-2}$ & $2.00 \times 10^{-16}$ & $\begin{array}{l}1.195051 \\
1.05748\end{array}$ & $1.57 \times 10^{-1}$ & $1.21 \times 10^{-7}$ & $\begin{array}{l}50 \\
36\end{array}$ & 0.00685 & 10.16 & $\begin{array}{l}0.91 \\
0.96\end{array}$ & $\begin{array}{l}-251.81 \\
-251\end{array}$ \\
\hline & $17 /$ N.A & $7.05628 \times 10^{-5}$ & $3.14 \times 10^{-5}$ & 0.313 & $\begin{array}{l}1.50010 \\
1.567122\end{array}$ & $1.19 \times 10^{-1}$ & $1.06 \times 10^{-14}$ & $\begin{array}{l}1.03740 \\
1.243728\end{array}$ & $1.49 \times 10^{-1}$ & $1.16 \times 10^{-9}$ & 36 & 0.01118 & $\begin{array}{l}10.10 \\
16.58\end{array}$ & $\begin{array}{l}0.90 \\
0.91\end{array}$ & -216.53 \\
\hline & Combined ages & 0.000071579 & $1.66 \times 10^{-5}$ & $3.69 \times 10^{-5}$ & 1.624 & $6.56 \times 10^{-2}$ & $2.00 \times 10^{-16}$ & 1.189 & $6.53 \times 10^{-2}$ & $2.00 \times 10^{-16}$ & 108 & 0.00932 & 13.84 & 0.91 & -698.38 \\
\hline & Maués & $5.37362 \times 10^{-5}$ & $1.53 \times 10^{-5}$ & 0.000757 & $\begin{array}{c}1.027 \\
1.584226\end{array}$ & $8.47 \times 10^{-2}$ & $2.00 \times 10^{-16}$ & 1.371793 & $1.04 \times 10^{-1}$ & $2.00 \times 10^{-16}$ & 72 & 0.00809 & 11.94 & 0.93 & -484.42 \\
\hline \multirow{5}{*}{4} & 10 years old & 0.000319856 & 0.0001926 & 0.106 & 1.998506808 & 0.2212336 & $1.47 \times 10^{-10}$ & - & - & - & 36 & 0.01273 & 20.23 & 0.76 & -208.09 \\
\hline & 12 years old & 0.000372362 & 0.0001272 & 0.00606 & 2.050015054 & 0.1270369 & $2.00 \times 10^{-16}$ & - & - & - & 36 & 0.01048 & 14.45 & 0.90 & -222.08 \\
\hline & 17/N.A years old & 0.001144129 & 0.0005888 & 0.0603 & 1.659720253 & 0.1976981 & $8.40 \times 10^{-10}$ & - & - & - & 36 & 0.01957 & 29.33 & 0.71 & -177.12 \\
\hline & Combined ages & 0.000883734 & 0.0003154 & 0.00604 & 1.694692783 & 0.133663 & $2.00 \times 10^{-16}$ & - & - & - & 108 & 0.01860 & 27.61 & 0.65 & -550.15 \\
\hline & Maués & 0.000446839 & 0.0001914 & 0.0224 & 1.925736118 & 0.1584811 & $2.00 \times 10^{-16}$ & - & - & - & 72 & 0.01564 & 23.09 & 0.72 & -390.46 \\
\hline \multirow{5}{*}{5} & 10 years old & $9.77357 \times 10^{-5}$ & $4.89 \times 10^{-5}$ & 0.0365 & 0.873384398 & $6.03 \times 10^{-2}$ & $4.20 \times 10^{-16}$ & - & - & & 36 & 0.00824 & 13.10 & 0.90 & -239.37 \\
\hline & 12 years old & $8.69155 \times 10^{-5}$ & $2.40 \times 10^{-5}$ & 0.00093 & $\begin{array}{c}0.8530835958 \\
0.9083541\end{array}$ & $3.59 \times 10^{-2}$ & $2.00 \times 10^{-16}$ & - & - & ـ & $\begin{array}{l}36 \\
36\end{array}$ & $\begin{array}{l}0.00824 \\
0.00684\end{array}$ & $\begin{array}{l}1.10 \\
9.43\end{array}$ & $\begin{array}{l}0.90 \\
0.96\end{array}$ & $\begin{array}{l}-259.37 \\
-252.79\end{array}$ \\
\hline & $17 /$ N.A & 0.000127887 & $5.60 \times 10^{-5}$ & 0.0286 & 0.85427041 & $5.69 \times 10^{-2}$ & $2.00 \times 10^{-16}$ & - & - & & 36 & 0.01225 & 18.36 & $\begin{array}{l}0.90 \\
0.89\end{array}$ & $\begin{array}{l}-202.19 \\
-210.85\end{array}$ \\
\hline & Combined ages & $9.64467 \times 10^{-5}$ & $2.45 \times 10^{-5}$ & 0.000145 & 0.8872781 & $3.31 \times 10^{-2}$ & $2.00 \times 10^{-16}$ & - & - & & 108 & 0.01040 & 15.43 & 0.89 & -675.86 \\
\hline & Maués & $9.87364 \times 10^{-5}$ & $2.46 \times 10^{-5}$ & 0.00182 & 0.9101592 & $4.03 \times 10^{-2}$ & $2.00 \times 10^{-16}$ & - & - & & 72 & 0.00929 & 13.72 & 0.90 & -465.40 \\
\hline
\end{tabular}


Table A3. Description of test results for the five models tested for tree dry mass calculation for each category containing parameters calculated for each equation $(a, b$, and $c$ ); Significance of the coefficients ( $p$ value); standard error of the coefficients (std error.); Number of sample trees used to calculate equation (n); Residuals (RSE and RSE\%), Coefficient of determination $\left(R^{2}\right)$ and Akaike index (AIC). N.A means Novo Aripuanã.

\begin{tabular}{|c|c|c|c|c|c|c|c|c|c|c|c|c|c|c|c|}
\hline Model & Variation & $a$ & Std. Error $a$ & $p$ Value $a$ & $b$ & Std. Error $b$ & $p$ Value $b$ & $c$ & Std. Error $c$ & $p$ Value $c$ & $n$ & RSE & RSE\% & $R^{2}$ & AIC \\
\hline \multirow{10}{*}{1} & Whole tree 10 & 12.27259 & 6.31445 & 0.0603 & 0.23382 & 0.03027 & $5.51 \times 10^{-9}$ & - & - & - & 36 & 11.81492 & 20.15 & 0.63 & 283.90 \\
\hline & Whole tree 12 & 3.18717 & 3.07645 & 0.308 & 0.29498 & 0.1667 & $2.00 \times 10^{-16}$ & - & - & - & 36 & 6.95191 & 12.97 & 0.90 & 245.72 \\
\hline & Whole tree $17 /$ N.A & 9.41361 & 5.9067 & 0.12 & 0.36872 & 0.03822 & $2.90 \times 10^{-11}$ & - & - & - & 36 & 15.84002 & 26.23 & 0.73 & 305.01 \\
\hline & Whole tree combined & 13.08642 & 3.66748 & 0.000541 & 0.26283 & 0.01994 & $2.00 \times 10^{-16}$ & - & - & - & 108 & 14.96293 & 26 & 0.62 & 894.88 \\
\hline & Whole tree Maués & 7.54355 & 3.32616 & 0.0264 & 0.26315 & 0.01689 & $2.00 \times 10^{-16}$ & - & - & - & 72 & 9.842599 & 17.54 & 0.77 & 537.59 \\
\hline & Canopy 10 & 6.23448 & 2.1792 & 0.00633 & 0.0698 & 0.01066 & $4.40 \times 10^{-8}$ & - & - & - & 48 & 4.855432 & 24.6 & 0.47 & 291.86 \\
\hline & Canopy 12 & 6.020556 & 1.346626 & $5.06 \times 10^{-5}$ & 0.037937 & 0.007468 & $6.72 \times 10^{-6}$ & - & - & - & 48 & 3.357062 & 27.07 & 0.35 & 256.44 \\
\hline & Canopy 17 & 5.40416 & 2.46842 & 0.0337 & 0.09899 & 0.01736 & $8.06 \times 10^{-7}$ & - & - & - & 48 & 7.893769 & 44.12 & 0.40 & 338.52 \\
\hline & Canopy combined & 6.870357 & 1.413232 & $3.05 \times 10^{-6}$ & 0.060308 & 0.007963 & $4.23 \times 10^{-12}$ & - & - & - & 144 & 6.790991 & 40.72 & 0.28 & 964.32 \\
\hline & Canopy Maués & 4.750729 & 1.534647 & 0.00259 & 0.06259 & 0.007963 & $6.28 \times 10^{-12}$ & - & - & - & 96 & 5.189632 & 32.29 & 0.39 & 592.57 \\
\hline \multirow{10}{*}{2} & Whole tree 10 & 4.8398 & 56.6492 & 0.932 & 1.0971 & 8.3079 & 0.896 & 0.1945 & 0.2995 & 0.521 & 36 & 11.98943 & 20.45 & 0.64 & 285.88 \\
\hline & Whole tree 12 & -17.9733 & 22.7429 & 0.435 & 3.337 & 3.5534 & 0.355 & 0.1688 & 0.1354 & 0.221 & 36 & 6.964018 & 12.99 & 0.91 & 246.77 \\
\hline & Whole tree $17 /$ N.A & -3.5761 & 36.5615 & 0.923 & 2.2113 & 6.1402 & 0.721 & 0.28 & 0.2493 & 0.269 & 36 & 16.04673 & 26.57 & 0.72 & 306.87 \\
\hline & Whole tree combined & 8.6451 & 24.5359 & 0.725 & 0.7148 & 3.9042 & 0.855 & 0.2354 & 0.1511 & 0.122 & 108 & 15.03161 & 26.12 & 0.62 & 896.84 \\
\hline & Whole tree Maués & -15.0742 & 25.7534 & 0.56 & 3.4724 & 3.9205 & 0.379 & 0.1347 & 0.146 & 0.36 & 72 & 9.857789 & 15.57 & 0.78 & 538.77 \\
\hline & Canopy 10 & 14.8512 & 20.3631 & 0.47 & -1.264 & 2.9696 & 0.672 & 0.1148 & 0.1063 & 0.286 & 48 & 4.899232 & 24.82 & 0.46 & 293.67 \\
\hline & Canopy 12 & -7.60925 & 9.71507 & 0.438 & 2.16486 & 1.52849 & 0.164 & -0.04482 & 0.0589 & 0.451 & 48 & 3.320945 & 26.77 & 0.36 & 256.34 \\
\hline & Canopy 17 & 11.1566 & 14.8714 & 0.457 & -1.0135 & 2.5832 & 0.697 & 0.1409 & 0.1082 & 0.2 & 48 & 7.967379 & 44.53 & 0.39 & 340.35 \\
\hline & Canopy combined & 12.37413 & 9.01858 & 0.1722 & -0.90114 & 1.45831 & 0.5376 & 0.095541 & 0.05736 & 0.0985 & 144 & 6.805821 & 40.81 & 0.28 & 965.94 \\
\hline & Canopy Maués & 0.60136 & 11.99269 & 0.96 & 0.63542 & 1.82127 & 0.728 & 0.03909 & 0.06782 & 0.566 & 96 & 5.214048 & 32.44 & 0.38 & 594.45 \\
\hline \multirow{10}{*}{3} & Whole tree 10 & 0.3576 & 0.1982 & $8.04 \times 10^{-2}$ & 1.1971 & 0.2035 & $1.37 \times 10^{-6}$ & 0.9179 & 0.2155 & $1.60 \times 10^{-4}$ & 36 & 9.601572 & 16.69 & 0.77 & 269.89 \\
\hline & Whole tree 12 & 0.13794 & 0.05135 & $1.12 \times 10^{-2}$ & 1.66283 & 0.10244 & $2.00 \times 10^{-16}$ & 0.74926 & 0.17504 & $1.51 \times 10^{-4}$ & 36 & 5.625728 & 9.78 & 0.94 & 231.40 \\
\hline & Whole tree $17 /$ N.A & 0.1981 & 0.1201 & $1.09 \times 10^{-1}$ & 1.6502 & 0.1605 & $8.01 \times 10^{-12}$ & 0.69066 & 0.201 & $1.61 \times 10^{-3}$ & 36 & 13.79181 & 23.97 & 0.81 & 295.96 \\
\hline & Whole tree combined & 0.14867 & 0.0472 & $2.13 \times 10^{-3}$ & 1.50003 & 0.09002 & $2.00 \times 10^{-16}$ & 0.93917 & 0.09174 & $2.00 \times 10^{-16}$ & 108 & 10.88936 & 18.92 & 0.81 & 827.21 \\
\hline & Whole tree Maués & 0.22506 & 0.07431 & $3.45 \times 10^{-3}$ & 1.55256 & 0.10377 & $2.00 \times 10^{-16}$ & 0.67511 & 0.1221 & $5.35 \times 10^{-7}$ & 72 & 8.171381 & 14.56 & 0.85 & 511.75 \\
\hline & Canopy 10 & 0.4073 & 0.2601 & $1.24 \times 10^{-1}$ & 1.2649 & 0.2458 & $5.66 \times 10^{-6}$ & 0.2643 & 0.2608 & $3.16 \times 10^{-1}$ & 48 & 4.883152 & 29.28 & 0.51 & 293.36 \\
\hline & Canopy 12 & 0.4897 & 0.3412 & 0.15815 & 0.9095 & 0.2184 & $1.40 \times 10^{-4}$ & 0.4157 & 0.3125 & $1.90 \times 10^{-1}$ & 48 & 3.279679 & 19.66 & 0.43 & 255.14 \\
\hline & Canopy 17 & 2.0833 & 2.0561 & 0.3164 & 1.4905 & 0.2415 & $1.74 \times 10^{-7}$ & -0.5971 & 0.3505 & $9.53 \times 10^{-2}$ & 48 & 7.791281 & 46.72 & 0.46 & 338.21 \\
\hline & Canopy combined & 0.4507 & 0.2553 & $7.97 \times 10^{-2}$ & 1.1659 & 0.1598 & $1.95 \times 10^{-11}$ & 0.2965 & 0.1757 & $9.37 \times 10^{-2}$ & 144 & 6.794992 & 40.74 & 0.30 & 965.48 \\
\hline & Canopy Maués & 0.5625 & 0.3198 & 0.0819 & 1.467 & 0.202 & $1.14 \times 10^{-10}$ & -0.2062 & 0.2248 & $3.61 \times 10^{-1}$ & 96 & 5.19405 & 32.32 & 0.41 & 593.71 \\
\hline \multirow{10}{*}{4} & Whole tree 10 & 0.9295 & 0.5422 & 0.0956 & 1.5704 & 0.2157 & $1.99 \times 10^{-8}$ & - & - & - & 36 & 11.81726 & 20.16 & 0.65 & 283.91 \\
\hline & Whole tree 12 & 0.45 & 0.1352 & 0.00211 & 1.862 & 0.1122 & $2.00 \times 10^{-16}$ & - & - & - & 36 & 6.909201 & 12.89 & 0.91 & 245.27 \\
\hline & Whole tree $17 /$ N.A & 0.9274 & 0.4287 & 0.0376 & 1.7006 & 0.1773 & $3.36 \times 10^{-11}$ & - & - & - & 36 & 15.76979 & 26.11 & 0.74 & 304.69 \\
\hline & Whole tree combined & 1.12 & 0.3724 & 0.0329 & 1.5415 & 0.125 & $2.00 \times 10^{-16}$ & - & - & - & 108 & 14.9801 & 26.03 & 0.62 & 895.12 \\
\hline & Whole tree Maués & 0.652 & 0.2076 & 0.00246 & 1.7111 & 0.1183 & $2.00 \times 10^{-16}$ & - & - & - & 72 & 9.799471 & 17.46 & 0.78 & 536.95 \\
\hline & Canopy 10 & 0.5301 & 0.3076 & 0.0916 & 1.3783 & 0.216 & $7.78 \times 10^{-8}$ & - & - & - & 48 & 4.883292 & 24.74 & 0.50 & 292.41 \\
\hline & Canopy 12 & 0.9462 & 0.5007 & 0.0651 & 1.0119 & 0.203 & $9.24 \times 10^{-6}$ & - & - & - & 48 & 3.306842 & 26.66 & 0.40 & 254.99 \\
\hline & Canopy 17 & 0.5243 & 0.3348 & 0.124 & 1.4674 & 0.2507 & $4.81 \times 10^{-7}$ & - & - & - & 48 & 7.94683 & 44.42 & 0.43 & 339.16 \\
\hline & Canopy combined & 0.8571 & 0.3638 & 0.0198 & 1.1744 & 0.1623 & $2.63 \times 10^{-11}$ & - & - & - & 144 & 6.83581 & 40.99 & 0.29 & 966.23 \\
\hline & Canopy Maués & 0.4273 & 0.2114 & 0.046 & 1.4011 & 0.1858 & $2.88 \times 10^{-11}$ & - & - & - & 96 & 5.188738 & 32.29 & 0.41 & 592.54 \\
\hline
\end{tabular}


Table A3. Cont.

\begin{tabular}{|c|c|c|c|c|c|c|c|c|c|c|c|c|c|c|c|}
\hline Model & Variation & $a$ & Std. Error $a$ & $p$ Value $a$ & $b$ & Std. Error $b$ & $p$ Value $b$ & $c$ & Std. Error $c$ & $p$ Value $c$ & $n$ & RSE & RSE $\%$ & $R^{2}$ & AIC \\
\hline \multirow{10}{*}{5} & Whole tree 10 & 0.38543 & 0.21111 & 0.0767 & 0.67969 & 0.07237 & $5.67 \times 10^{-11}$ & - & - & - & 36 & 9.64982 & 16.46 & 0.76 & 269.32 \\
\hline & Whole tree 12 & 0.12585 & 0.03757 & 0.00199 & 0.8187 & 0.039 & $2.00 \times 10^{-16}$ & - & - & - & 36 & 5.55605 & 10.36 & 0.94 & 229.58 \\
\hline & Whole tree $17 /$ N.A & 0.1674 & 0.09033 & 0.0726 & 0.80382 & 0.07036 & $3.46 \times 10^{-13}$ & - & - & - & 36 & 13.65881 & 22.62 & 0.81 & 294.34 \\
\hline & Whole tree combined & 0.17609 & 0.05477 & 0.00173 & 0.78505 & 0.04075 & $2.00 \times 10^{-16}$ & - & - & - & 108 & 11.00579 & 19.13 & 0.80 & 828.53 \\
\hline & Whole tree Maués & 0.2089 & 0.06623 & 0.00237 & 0.75644 & 0.04166 & $2.00 \times 10^{-16}$ & - & - & - & 72 & 8.141281 & 14.51 & 0.85 & 510.26 \\
\hline & Canopy 10 & 0.37289 & 0.24026 & 0.128 & 0.5837 & 0.08557 & $1.06 \times 10^{-7}$ & - & - & 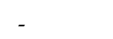 & 48 & 4.890941 & 24.78 & 0.50 & 292.56 \\
\hline & Canopy 12 & 0.47157 & 0.29126 & 0.112 & 0.44809 & 0.08289 & $2.23 \times 10^{-6}$ & - & - & - & 48 & 3.244245 & 26.16 & 0.43 & 253.16 \\
\hline & Canopy 17 & 0.2885 & 0.273 & 0.296 & 0.5726 & 0.1266 & $4.30 \times 10^{-5}$ & - & - & - & 48 & 8.675436 & 48.49 & 0.32 & 347.58 \\
\hline & Canopy combined & 0.3358 & 0.18043 & 0.0648 & 0.53527 & 0.07173 & $7.79 \times 10^{-12}$ & - & - & - & 144 & 6.822263 & 40.91 & 0.29 & 965.66 \\
\hline & Canopy Maués & 0.33253 & 0.19817 & 0.0967 & 0.52844 & 0.07941 & $1.87 \times 10^{-9}$ & - & 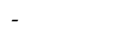 & . & 96 & 5.459923 & 33.97 & 0.35 & 602.32 \\
\hline
\end{tabular}

Table A4. Description of test results for the five models tested for tree fresh mass calculation for each category containing parameters calculated for each equation $(a, b$, and $c$ ); Significance of the coefficients (p value); standard error of the coefficients (std error.); Number of sample trees used to calculate equation ( $n$ ); Residuals (RSE and RSE\%), Coefficient of determination $\left(R^{2}\right)$ and Akaike index (AIC). N.A. means Novo Aripuanã.

\begin{tabular}{|c|c|c|c|c|c|c|c|c|c|c|c|c|c|c|c|}
\hline Model & Variation & $a$ & Std. Error $a$ & $p$ Value $a$ & $b$ & Std. Error $b$ & $p$ Value $b$ & $c$ & Std. Error $c$ & $p$ Value $c$ & $n$ & RSE & RSE $\%$ & $R^{2}$ & AIC \\
\hline \multirow{10}{*}{1} & Whole tree 10 & 21.61689 & 10.99357 & 0.0575 & 0.4079 & 0.05269 & $5.27 \times 10^{-9}$ & - & - & - & 36 & 20.57 & 20.07 & 0.63 & 323.82 \\
\hline & Whole tree 12 & 6.0764 & 5.1853 & 0.249 & 0.4903 & 0.0281 & $2.00 \times 10^{-16}$ & - & - & - & 36 & 11.72 & 13.03 & 0.90 & 283.30 \\
\hline & Whole tree $17 /$ N.A & 14.75406 & 9.35753 & 0.124 & 0.58551 & 0.6055 & $2.74 \times 10^{-11}$ & - & - & - & 36 & 25.09 & 26.22 & 0.73 & 338.14 \\
\hline & Whole tree combined & 19.4996 & 5.53868 & 0.000636 & 0.45241 & 0.3012 & $2.00 \times 10^{-16}$ & - & - & - & 108 & 22.60 & 23.53 & 0.68 & 983.92 \\
\hline & Whole tree Maués & 12.71452 & 5.6557 & 0.0277 & 0.45218 & 0.02872 & $2.00 \times 10^{-16}$ & - & - & - & 72 & 16.74 & 17.4 & 0.78 & 614.03 \\
\hline & Canopy 10 & 10.96819 & 4.90701 & 0.0321 & 0.13193 & 0.02314 & $2.10 \times 10^{-6}$ & - & - & - & 48 & 8.76 & 24.6 & 0.47 & 348.51 \\
\hline & Canopy 12 & 17.24565 & 3.51823 & $2.30 \times 10^{-5}$ & 0.04611 & 0.01914 & $2.15 \times 10^{-2}$ & - & - & - & 48 & 6.03 & 27.07 & 0.35 & 312.63 \\
\hline & Canopy 17 & 10.54234 & 2.483 & 0.000159 & 0.07796 & 0.1625 & $3.14 \times 10^{-5}$ & - & - & - & 48 & 12.21 & 44.12 & 0.40 & 380.42 \\
\hline & Canopy combined & 10.22513 & 2.22657 & $9.57 \times 10^{-6}$ & 0.11251 & 0.01255 & $1.60 \times 10^{-15}$ & - & - & - & 144 & 10.70 & 37.51 & 0.36 & 1095.25 \\
\hline & Canopy Maués & 11.26083 & 3.4854 & 0.00188 & 0.10749 & 0.01756 & $4.80 \times 10^{-8}$ & - & - & - & 96 & 9.39 & 32.43 & 0.39 & 706.36 \\
\hline \multirow{10}{*}{2} & Whole tree 10 & 9.3245 & 98.6298 & 0.925 & 1.8144 & 14.4646 & 0.901 & 0.3428 & 0.5214 & 0.515 & 36 & 20.87 & 20.37 & 0.64 & 325.80 \\
\hline & Whole tree 12 & -31.4192 & 38.2788 & 0.418 & 5.913 & 5.9808 & 0.33 & 0.2667 & 0.2278 & 0.25 & 36 & 11.72 & 13.04 & 0.90 & 284.25 \\
\hline & Whole tree $17 /$ N.A & -6.5822 & 57.9131 & 0.91 & 3.6322 & 9.726 & 0.711 & 0.4398 & 0.3949 & 0.273 & 36 & 25.42 & 26.56 & 0.73 & 339.98 \\
\hline & Whole tree combined & 5.9292 & 37.03262 & 0.873 & 2.1841 & 5.8933 & 0.712 & 0.3686 & 0.2281 & 0.109 & 108 & 22.69 & 23.63 & 0.68 & 985.78 \\
\hline & Whole tree Maués & -28.3408 & 43.7556 & 0.519 & 6.303 & 6.6611 & 0.347 & 0.219 & 0.2481 & 0.381 & 72 & 16.75 & 17.41 & 0.78 & 615.10 \\
\hline & Canopy 10 & 26.793 & 36.7369 & 0.47 & -2.2803 & 5.3574 & 0.672 & 0.2071 & 0.1918 & 0.286 & 48 & 8.84 & 24.82 & 0.48 & 350.32 \\
\hline & Canopy 12 & -13.66282 & 17.44392 & 0.438 & 3.88712 & 2.74449 & 0.164 & -0.08048 & 0.10575 & 0.451 & 48 & 5.96 & 26.77 & 0.39 & 312.53 \\
\hline & Canopy 17 & 17.2627 & 23.0106 & 0.457 & -1.5683 & 3.997 & 0.697 & 0.218 & 0.1674 & 0.2 & 48 & 12.33 & 44.53 & 0.42 & 382.26 \\
\hline & Canopy combined & 14.94215 & 14.22244 & 0.295 & -0.77233 & 2.29977 & 0.738 & 0.14259 & 0.09046 & 0.117 & 144 & 10.73 & 37.63 & 0.36 & 1097.14 \\
\hline & Canopy Maués & 1.06925 & 21.69248 & 0.961 & 1.14072 & 3.29432 & 0.73 & 0.07073 & 0.12268 & 0.566 & 96 & 9.43 & 32.59 & 0.40 & 708.24 \\
\hline
\end{tabular}


Table A4. Cont.

\begin{tabular}{|c|c|c|c|c|c|c|c|c|c|c|c|c|c|c|c|}
\hline Model & Variation & $a$ & Std. Error $a$ & $p$ Value $a$ & $b$ & Std. Error $b$ & $p$ Value $b$ & $c$ & Std. Error $c$ & $p$ Value $c$ & $n$ & RSE & RSE $\%$ & $R^{2}$ & AIC \\
\hline \multirow{10}{*}{3} & Whole tree 10 & 0.6401154 & 0.355 & $8.05 \times 10^{-2}$ & 1.199 & 0.2039 & $1.37 \times 10^{-6}$ & 0.9044 & 0.2157 & $1.94 \times 10^{-4}$ & 36 & 16.82 & 17.51 & 0.77 & 310.24 \\
\hline & Whole tree 12 & 0.24537 & 0.09252 & $1.22 \times 10^{-2}$ & 1.64861 & 0.10386 & $2.00 \times 10^{-16}$ & 0.073956 & 0.17752 & $2.10 \times 10^{-4}$ & 36 & 9.56 & 9.96 & 0.94 & 269.61 \\
\hline & Whole tree $17 /$ N.A & 0.303 & 0.1824 & $1.06 \times 10^{-1}$ & 1.6517 & 0.1593 & $6.52 \times 10^{-12}$ & 0.7036 & 0.1994 & $1.25 \times 10^{-3}$ & 36 & 21.69 & 22.59 & 0.81 & 328.58 \\
\hline & Whole tree combined & 0.31046 & 0.09485 & $1.44 \times 10^{-3}$ & 1.54806 & 0.08716 & $2.00 \times 10^{-16}$ & 0.78635 & 0.08891 & $2.38 \times 10^{-14}$ & 108 & 17.48 & 18.21 & 0.81 & 929.46 \\
\hline & Whole tree Maués & 0.4491 & 0.154 & $4.79 \times 10^{-3}$ & 1.5767 & 0.1087 & $2.00 \times 10^{-16}$ & 0.5773 & 0.1267 & $2.19 \times 10^{-5}$ & 72 & 14.66 & 15.24 & 0.84 & 595.88 \\
\hline & Canopy 10 & 0.7348 & 0.4692 & $1.24 \times 10^{-1}$ & 1.2649 & 0.2458 & $5.66 \times 10^{-6}$ & 0.2643 & 0.2608 & $3.16 \times 10^{-1}$ & 48 & 8.81 & 30.89 & 0.51 & 350.00 \\
\hline & Canopy 12 & 0.8792 & 0.6126 & 0.15815 & 0.9095 & 0.2184 & $1.40 \times 10^{-4}$ & 0.4157 & 0.3125 & $1.90 \times 10^{-1}$ & 48 & 5.89 & 20.65 & 0.43 & 311.33 \\
\hline & Canopy 17 & 3.2235 & 3.1814 & 0.3164 & 1.4905 & 0.2415 & $1.74 \times 10^{-7}$ & -0.5971 & 0.3505 & $9.53 \times 10^{-2}$ & 48 & 12.06 & 42.27 & 0.46 & 380.11 \\
\hline & Canopy combined & 0.94096 & 0.49099 & $5.73 \times 10^{-2}$ & 1.28087 & 0.15078 & $2.52 \times 10^{-14}$ & 0.07649 & 0.16372 & $6.41 \times 10^{-1}$ & 144 & 10.78 & 37.81 & 0.37 & 1098.48 \\
\hline & Canopy Maués & 1.0139 & 0.5787 & 0.0831 & 1.4715 & 0.2029 & $1.20 \times 10^{-10}$ & -2121 & 0.2256 & $3.50 \times 10^{-1}$ & 96 & 9.39 & 32.46 & 0.41 & 707.46 \\
\hline \multirow{10}{*}{4} & Whole tree 10 & 1.6381 & 0.9515 & 0.0942 & 1.5673 & 0.2149 & $1.90 \times 10^{-8}$ & - & - & - & 36 & 20.57 & 20.08 & 0.65 & 323.84 \\
\hline & Whole tree 12 & 0.7884 & 0.2376 & 0.00217 & 18452 & 0.1126 & $2.00 \times 10^{-16}$ & - & - & - & 36 & 11.63 & 12.94 & 0.90 & 282.79 \\
\hline & Whole tree $17 /$ N.A & 1.4605 & 0.6748 & 0.0376 & 1.7031 & 0.1772 & $3.19 \times 10^{-11}$ & - & - & - & 36 & 24.98 & 26.1 & 0.74 & 337.80 \\
\hline & Whole tree together & 1.6607 & 0.5011 & 0.00126 & 1.5872 & 0.1133 & $2.00 \times 10^{-16}$ & - & - & - & 108 & 22.59 & 23.52 & 0.68 & 983.84 \\
\hline & Whole tree Maués & 1.108 & 0.3498 & 0.00228 & 1.7144 & 0.1173 & $2.00 \times 10^{-16}$ & - & - & - & 72 & 16.66 & 17.32 & 0.78 & 613.33 \\
\hline & Canopy 10 & 0.9563 & 0.555 & 0.0916 & 1.3783 & 0.216 & $7.78 \times 10^{-8}$ & - & - & - & 48 & 8.81 & 24.74 & 0.50 & 349.06 \\
\hline & Canopy 12 & 1.699 & 0.899 & 0.0651 & 1.012 & 0.203 & $2.24 \times 10^{-6}$ & - & - & - & 48 & 5.94 & 26.66 & 0.40 & 311.18 \\
\hline & Canopy 17 & 0.8113 & 0.518 & 0.124 & 1.4674 & 0.2507 & $4.81 \times 10^{-7}$ & - & - & - & 48 & 12.30 & 44.42 & 0.43 & 381.07 \\
\hline & Canopy combined & 1.107 & 0.4369 & 0.0124 & 1.2843 & 0.1504 & $1.87 \times 10^{-14}$ & - & - & - & 144 & 10.75 & 37.7 & 0.36 & 1096.69 \\
\hline & Canopy Maués & 0.7643 & 1.4037 & 0.047 & 1.4037 & 0.1866 & $3.18 \times 10^{-11}$ & - & - & - & 96 & 9.39 & 32.43 & 0.41 & 706.33 \\
\hline \multirow{10}{*}{5} & Whole tree 10 & 0.68739 & 0.37622 & 0.0765 & 0.67701 & 0.07232 & $6.15 \times 10^{-11}$ & - & - & - & 36 & 16.90 & 16.46 & 0.76 & 309.54 \\
\hline & Whole tree 12 & 0.2232 & 0.06749 & 0.00223 & 0.8112 & 0.03952 & $2.00 \times 10^{-16}$ & - & - & - & 36 & 9.45 & 10.51 & 0.94 & 267.80 \\
\hline & Whole tree 17/N.A & 0.26002 & 0.13919 & 0.0704 & 0.80651 & 0.06978 & $2.53 \times 10^{-13}$ & - & - & - & 36 & 21.47 & 22.43 & 0.81 & 326.89 \\
\hline & Whole tree combined & 0.319 & 0.09231 & 0.000949 & 0.77631 & 0.03854 & $2.00 \times 10^{-16}$ & - & - & - & 108 & 17.40 & 18.12 & 0.81 & 927.48 \\
\hline & Whole tree Maués & 0.38526 & 0.12886 & 0.00385 & 0.74665 & 0.04396 & $2.00 \times 10^{-16}$ & - & - & - & 72 & 14.75 & 15.34 & 0.83 & 595.88 \\
\hline & Canopy 10 & 0.67274 & 0.43345 & 0.128 & 0.5387 & 0.08557 & $1.06 \times 10^{-7}$ & - & - & - & 48 & 8.82 & 24.78 & 0.50 & 349.21 \\
\hline & Canopy 12 & 0.84672 & 0.52297 & 0.44809 & 0.08289 & $2.23 \times 10^{-6}$ & $6.66 \times 10^{-7}$ & - & - & - & 48 & 5.83 & 26.16 & 0.43 & 309.35 \\
\hline & Canopy 17 & $\begin{array}{l}0.446 / 2 \\
0.4464\end{array}$ & 0.4225 & $\begin{array}{l}0.296 \\
0.296\end{array}$ & $\begin{array}{l}0.00209 \\
0.5726\end{array}$ & 0.1266 & $4.30 \times 10^{-5}$ & - & - & - & 48 & $\begin{array}{l}3.03 \\
13.42\end{array}$ & 48.49 & 0.32 & 389.49 \\
\hline & Canopy combined & 0.53792 & 0.27526 & 0.0526 & 0.54422 & 0.06828 & $4.70 \times 10^{-13}$ & - & - & - & 144 & 11.10 & 38.93 & 0.32 & 1105.94 \\
\hline & Canopy Maués & 0.59702 & 0.3575 & $\begin{array}{l}0.0920 \\
0.0982\end{array}$ & 0.52884 & $\begin{array}{l}0.00020 \\
0.07978\end{array}$ & $2.12 \times 10^{-9}$ & - & - & - & $\begin{array}{l}144 \\
96\end{array}$ & 9.88 & 34.13 & 0.34 & 716.17 \\
\hline
\end{tabular}


Table A5. $R$ software output table with ANCOVA significance values resulting for volume using C 10 as reference for comparison of $\mathrm{C} 12$ and $\mathrm{C} 17$.

\begin{tabular}{lllll}
\hline \multicolumn{5}{c}{ Coefficients } \\
\hline- & Stimate & Std. Error & $t$ Value & $\operatorname{Pr}(>|t|)$ \\
\hline (Intercept) & -9.28771 & 0.32522 & -28.558 & $<2 \times 10^{-16 * * *}$ \\
$\log$ (dados\$dap) & 1.53447 & 0.1577 & 9.73 & $4.24 \times 10^{-16 * * *}$ \\
$\log$ (dados\$ht) & 1.16045 & 0.15092 & 7.689 & $1.11 \times 10^{-11 * * *}$ \\
dado\$\$dade12 & -0.45012 & 0.51502 & -0.874 & 0.384 \\
dados\$idade17 & 0.02887 & 0.45181 & -0.064 & 0.949 \\
$\log ($ dados\$dap):dados\$idade12 & 0.16933 & 0.19707 & 0.859 & 0.392 \\
$\log$ (dados\$dap):dados\$dade17 & 0.10568 & 0.18198 & 0.581 & 0.563 \\
$\log$ (dados\$ht):dados\$idade12 & 0.04638 & 0.25584 & 0.181 & 0.857 \\
$\log$ (dados\$ht):dados\$idade17 & -0.09858 & 0.19645 & -0.502 & 0.617 \\
\hline
\end{tabular}

The first volumn mean intercept related to DBH, Below: height-related intercept, Below: age-related intercept C 12, Below: age-related intercept $C 17$ when comared with $C 10$, Below: DBH-related coefficient between $C 10$ and $C 12$, Below: DBH-related coefficient between C 10 and C 17, Below: height-related coefficient between C 10 and C 12, Below: height-related coefficient between C 10 and C 17, respectively. Signif. codes: “***": 0-0.001.

Table A6. $R$ software output table with ANCOVA significance values resulting for volume using C 12 as reference for comparison of C 10 and C 17.

\begin{tabular}{lllll}
\hline \multicolumn{5}{c}{ Coefficients } \\
\hline- & Estimate & Std. Error & $t$ Value & $\operatorname{Pr}(>|t|)$ \\
\hline (Intercept) & -9.73783 & 0.39935 & -24.384 & $<2 \times 10^{-16 * * *}$ \\
$\log$ (dados\$dap) & 1.7038 & 0.11819 & 14.416 & $<2 \times 10^{-16 * * *}$ \\
$\log$ (dados\$ht) & 1.20683 & 0.20658 & 5.842 & $6.6 \times 10^{-8 * * *}$ \\
dados\$idade_1210 & 0.45012 & 0.51502 & 0.874 & 0.384 \\
dados\$idade_1217 & 0.42125 & 0.50779 & 0.83 & 0.409 \\
$\log$ (dados\$dap):dados\$idade_1210 & -0.16933 & 0.19707 & -0.859 & 0.392 \\
$\log$ (dados\$dap):dadod\$idade_1217 & -0.06364 & 0.14905 & -0.427 & 0.67 \\
$\log$ (dados\$ht):dados\$idade_1210 & -0.04638 & 0.25584 & -0.181 & 0.857 \\
$\log$ (dados\$ht):dados\$idade_1217 & -0.14496 & 0.24185 & -0.599 & 0.55 \\
\hline
\end{tabular}

Signif. codes: Signif. codes: “***”: 0-0.001.

Table A7. $R$ software output table with significance values resulting from ANCOVA for AGDM using C 10 as reference for comparison with C 12 and C 17.

\begin{tabular}{lllll}
\hline \multicolumn{5}{c}{ Coefficients } \\
\hline - & Estimate & Std. Error & $\boldsymbol{t}$ Value & $\operatorname{Pr}(>|t|)$ \\
\hline (Intercept) & -0.3510 & 0.5294 & -0.663 & 0.5089 \\
$\log ($ dados\$dap) & 1.0713 & 0.2567 & 4.173 & $6.47 \times 10^{-5 * * *}$ \\
$\log ($ dados\$ht) & 0.7505 & 0.2457 & 3.054 & $0.0029^{* *}$ \\
dados\$idade12 & -1.6936 & 0.8384 & -2.020 & $0.0461^{*}$ \\
dados\$idade17 & -0.4321 & 0.7355 & -0.588 & 0.5582 \\
$\log ($ dados\$dap):dados\$idade12 & 0.7247 & 0.3208 & 2.259 & $0.0261^{*}$ \\
$\log ($ dados\$dap):dados\$idade17 & 0.3661 & 0.2963 & 1.236 & 0.2195 \\
$\log ($ dados\$ht):dados\$idade12 & -0.1273 & 0.4165 & -0.306 & 0.7606 \\
$\log$ (dados\$ht):dados\$idade17 & -0.2006 & 0.3198 & -0.627 & 0.532 \\
\hline
\end{tabular}

Signif. codes: “***”: 0-0.001; “**”: $0.001-0.01 ; “ * *$ : 0.01-0.05. 
Table A8. $R$ software output table with significance values resulting from ANCOVA for AGDM using C 12 as reference for comparison with C 10 and C 17 .

\begin{tabular}{lllll}
\hline \multicolumn{5}{c}{ Coefficients } \\
\hline- & Estimate & Std. Error & $t$ Value & $\operatorname{Pr}(>|t|)$ \\
\hline (Intercept) & -2.04455 & 0.65013 & -3.145 & $0.00219^{* *}$ \\
$\log$ (dados\$dap) & 1.79596 & 0.19241 & 9.334 & $3.1 \times 10^{-15 * * *}$ \\
$\log$ (dados\$ht) & 0.62321 & 0.33631 & 1.853 & 0.06685. \\
dados\$idade_1210 & 1.69358 & 0.83844 & 2.02 & $0.04609 *$ \\
dados\$idade_1217 & 1.26144 & 0.82666 & 1.526 & 0.13021 \\
$\log$ (dados\$dap):dados\$idade_1210 & -0.72470 & 0.32083 & -2.259 & $0.02609 *$ \\
$\log$ (dados\$dap):dado\$idade_1217 & -0.35862 & 0.24266 & -1.478 & 0.14261 \\
$\log$ (dados\$ht):dados\$idade_1210 & 0.12726 & 0.4165 & 0.306 & 0.7606 \\
$\log$ (dados\$ht):dados\$idade_1217 & -0.07334 & 0.39373 & -0.186 & 0.85262 \\
\hline
\end{tabular}

Signif. codes: “***”: 0-0.001; “**”: 0.001-0.01; “*”: 0.01-0.05; “.”: 0.05-0.1.

Table A9. $R$ output of ANOVA among the residues generated from the estimation of AGDM using species equation and age specific equation with $\mathrm{C} 12$.

\begin{tabular}{lccccc}
\hline \multicolumn{5}{c}{ Analysis of Variance Table } \\
\hline Response: res & Df & Sum Sq & Mean Sq & $\boldsymbol{F}$ Value & $\operatorname{Pr}(>\boldsymbol{F})$ \\
\hline trat & 1 & 384.59 & 384.59 & 12.369 & $0.0007708^{* * *}$ \\
Residuals & 70 & 2176.49 & 31.09 & & \\
\hline \multicolumn{7}{c}{ Signif. codes: “***”: $0-0.001}$.
\end{tabular}

Table A10. $R$ software output table with significance values resulting from ANCOVA for CDM using C 12 as reference for comparison with C 10 and C 17.

\begin{tabular}{lllll}
\hline \multicolumn{5}{c}{ Coefficients } \\
\hline- & Estimate & Std. Error & $t$ Value & $\operatorname{Pr}(>|t|)$ \\
\hline (Intercept) & -0.91285 & 0.86428 & -1.056 & 0.2928 \\
$\log ($ dado\$\$dap) & 1.14182 & 0.25152 & 4.54 & $1.23 \times 10^{-5} * * *$ \\
$\log ($ dados\$ht) & 0.22081 & 0.39124 & 0.564 & 0.5734 \\
dados\$idade_1210 & 0.20288 & 1.13949 & 0.178 & 0.859 \\
dados\$idade_1217 & 2.08225 & 1.13886 & 1.828 & 0.0697. \\
$\log ($ dados\$dap):dados\$idade_1210 & 0.04724 & 0.41071 & 0.115 & 0.9086 \\
$\log ($ dados\$dap):dados\$idade_1217 & 0.12834 & 0.31721 & 0.405 & 0.6864 \\
$\log ($ dados\$ht):dados\$dade_1210 & 0.03345 & 0.50601 & 0.066 & 0.9474 \\
$\log ($ dados\$ht):dados\$idade_1217 & -0.80873 & 0.48437 & -1.670 & 0.0973. \\
\hline
\end{tabular}

Signif. codes: “***”: 0-0.001; “.”: 0.05-0.1.

Table A11. $R$ software output table with significance values resulting from ANCOVA for CDM using C 10 as reference for comparison with C 12 and C 17 .

\begin{tabular}{lllll}
\hline \multicolumn{5}{c}{ Coefficients } \\
\hline- & Estimate & Std. Error & $\boldsymbol{t}$ value & $\operatorname{Pr}(>|t|)$ \\
\hline (Intercept) & -0.70997 & 0.7426 & -0.956 & 0.340752 \\
$\log$ (dados\$dap) & 1.18906 & 0.32469 & 3.662 & 0.000358 *** \\
$\log$ (dados\$ht) & 0.25426 & 0.32089 & 0.792 & 0.429538 \\
dados\$idade12 & -0.20288 & 1.13949 & -0.178 & 0.858957 \\
dados\$idade17 & 1.87937 & 1.04952 & 1.791 & 0.075582. \\
$\log$ (dados\$dap):dados\$idade12 & -0.04724 & 0.41071 & -0.115 & 0.908592 \\
$\log$ (dados\$dap):dados\$idade17 & 0.0811 & 0.37787 & 0.215 & 0.830392 \\
$\log$ (dados\$ht):dados\$idade12 & -0.03345 & 0.50601 & 0.066 & 0.94739 \\
$\log$ (dados\$ht):dados\$idade17 & 0.84218 & 0.42956 & -1.961 & 0.051986. \\
\hline
\end{tabular}

Signif. codes: “****: 0-0.001;“.": 0.05-0.1. 
Table A12. $R$ output of ANOVA among the residues generated from the estimation of CDM using species equation and age specific equation for $\mathrm{C} 17$.

\begin{tabular}{lccccc}
\hline \multicolumn{5}{c}{ Analysis of Variance Table } \\
\hline Response: res & Df & Sum Sq & Mean Sq & F Value & Pr $(>\boldsymbol{F})$ \\
\hline trat & 1 & 194.4 & 194.395 & 3.0435 & 0.08433. \\
Residuals & 94 & 6004 & 63.872 & & \\
\hline
\end{tabular}

Signif. codes: ".": 0.05-0.1.

Table A13. $R$ software output table with significance values resulting from ANCOVA for AGFM using $\mathrm{C} 10$ as reference for comparison with $\mathrm{C} 12$ and C 17.

\begin{tabular}{lllll}
\hline \multicolumn{5}{c}{ Coefficients } \\
\hline- & Estimate & Std. Error & $t$ value & $\operatorname{Pr}(>|t|)$ \\
\hline (Intercept) & 0.2278 & 0.529 & 0.431 & 0.66771 \\
$\log$ (dados\$dap) & 1.0739 & 0.2565 & 4.186 & $6.15 \times 10^{-5 * * *}$ \\
$\log ($ dados\$ht) & 0.7376 & 0.2455 & 3.004 & $0.00337^{* *}$ \\
dados\$idade12 & -1.6982 & 0.8378 & -2.027 & $0.04536^{*}$ \\
dados\$idade17 & -0.5858 & 0.735 & -0.797 & 0.42737 \\
$\log ($ dados\$dap):dados\$idade12 & 0.7123 & 0.3206 & 2.222 & $0.02857^{*}$ \\
$\log ($ dados\$dap):dados\$idade17 & 0.3654 & 0.296 & 1.234 & 0.22007 \\
$\log ($ dados\$ht):dados\$idade12 & -0.1285 & 0.4162 & -0.309 & 0.75824 \\
$\log$ (dados\$ht):dados\$idade17 & -0.1750 & 0.3196 & -0.548 & 0.58522 \\
\hline
\end{tabular}

Signif. codes: “***”: $0-0.001 ; “ * * ": 0.001-0.01 ; “ * *: 0.01-0.05$.

Table A14. $R$ software output table with significance values resulting from ANCOVA for AGFM using C 12 as reference for comparison with C 10 and C 17.

\begin{tabular}{|c|c|c|c|c|}
\hline \multicolumn{5}{|c|}{ Coefficients } \\
\hline- & Estimate & Std. Error & $t$ Value & $\operatorname{Pr}(>|t|)$ \\
\hline (Intercept) & -1.47042 & 0.64965 & -2.263 & $0.0258 *$ \\
\hline $\log ($ dados $\$$ dap $)$ & 1.7862 & 0.19227 & 9.29 & $3.87 \times 10^{-15 * * *}$ \\
\hline $\log ($ dados $\$ h t)$ & 0.60913 & 0.33606 & 1.813 & 0.0729 . \\
\hline dados\$idade_1210 & 1.69821 & 0.83781 & 2.027 & $0.0454 *$ \\
\hline dados\$idade_1217 & 1.11244 & 0.82604 & 1.347 & 0.1811 \\
\hline $\log ($ dados $\$$ dap):dados\$idade_1210 & -0.71229 & 0.32059 & -2.222 & $0.0286 *$ \\
\hline $\log ($ dados $\$$ dap):dados\$idade_1217 & -0.34693 & 0.24247 & -1.431 & 0.1556 \\
\hline $\log ($ dados\$ht):dados\$idade_1210 & 0.12845 & 0.41619 & 0.309 & 0.7582 \\
\hline $\log ($ dados\$ht):dados\$idade_1217 & -0.04653 & 0.39343 & -0.118 & 0.9061 \\
\hline
\end{tabular}

Signif. codes: “***”: 0-0.001; “*”: 0.01-0.05; “"”: 0.05-0.1.

Table A15. $R$ output of Anova among the residues generated from the estimation of AGFM using species equation and age specific equation for $C 12$.

\begin{tabular}{lccccc}
\hline \multicolumn{5}{c}{ Analysis of Variance Table } \\
\hline Response: res & Df & Sum Sq & Mean Sq & $\boldsymbol{F}$ Value & Pr $(>\boldsymbol{F})$ \\
\hline trat & 1 & 1003.6 & 1003.56 & 11.48 & $0.001158^{* *}$ \\
Residuals & 70 & 6119.3 & 87.42 & & \\
\hline \multicolumn{7}{c}{ Signif. codes: “**”: $0.001-0.01}$.
\end{tabular}


Table A16. $R$ output of ANOVA among the residues generated from the estimation of AGFM using species equation and age specific equation for $C 10$.

\begin{tabular}{lccccc}
\hline \multicolumn{5}{c}{ Analysis of Variance Table } \\
\hline Response: res & Df & Sum Sq & Mean Sq & $\boldsymbol{F}$ Value & $\operatorname{Pr}(>\boldsymbol{F})$ \\
\hline trat & 1 & 345 & 345.03 & 1.2659 & 0.2644 \\
Residuals & 70 & 19,078 & 272.55 & & \\
\hline
\end{tabular}

Table A17. $R$ software output table with significance values resulting from ANCOVA for CFM using C 10 as reference for comparison of C 12 and C 17.

\begin{tabular}{lllll}
\hline \multicolumn{5}{c}{ Coefficients } \\
\hline- & Estimate & Std. Error & $t$ Value & $\operatorname{Pr}(>|t|)$ \\
\hline (Intercept) & -0.11991 & 0.7426 & -0.161 & 0.871958 \\
$\log ($ dados\$dap) & 1.18906 & 0.32469 & 3.662 & 0.000358 *** \\
$\log$ (dados\$ht) & 0.25426 & 0.32089 & 0.792 & 0.429538 \\
dados\$idade12 & -0.20762 & 1.13949 & -0.182 & 0.855695 \\
dados\$idade17 & 1.72583 & 1.04952 & 1.644 & 0.10242 \\
$\log ($ dados\$dap):dados\$idade12 & -0.04724 & 0.41071 & -0.115 & 0.908592 \\
$\log ($ dados\$dap):dados\$idade17 & 0.0811 & 0.37787 & 0.215 & 0.830392 \\
$\log ($ dados\$ht):dados\$idade12 & -0.03345 & 0.50601 & -0.066 & 0.94739 \\
$\log$ (dados\$ht):dados\$idade17 & -0.84218 & 0.42956 & -1.961 & 0.051986. \\
\hline
\end{tabular}

Signif. codes: “***”: 0-0.001;“.": 0.05-0.1.

Table A18. $R$ software output table with significance values resulting from ANCOVA for CFM using C12 as reference for comparison with C 10 and C 17.

\begin{tabular}{lllll}
\hline \multicolumn{5}{c}{ Coefficients } \\
\hline- & Estimate & Std. Error & $t$ Value & $\operatorname{Pr}(>|t|)$ \\
\hline (Intercept) & -0.32754 & 0.86428 & -0.379 & 0.7053 \\
$\log$ (dados\$dap) & 1.14182 & 0.25152 & 4.54 & $1.23 \times 10^{-5} * * *$ \\
$\log$ (dados\$ht) & 0.22081 & 0.39124 & 0.564 & 0.5734 \\
dados\$idade_1210 & 0.20762 & 1.13949 & 0.182 & 0.8557 \\
dados\$idade_1217 & 1.93345 & 1.13886 & 1.698 & 0.0919. \\
$\log$ (dados\$dap):dados\$idade_1210 & 0.04724 & 0.41071 & 0.115 & 0.9086 \\
$\log$ (dados\$dap):dado\$\$idade_1217 & 0.12834 & 0.31721 & 0.405 & 0.6864 \\
$\log$ (dados\$ht):dados\$idade_1210 & 0.03345 & 0.50601 & 0.066 & 0.9474 \\
$\log$ (dados\$ht):dados\$idade_1217 & -0.80873 & 0.48437 & -1.670 & 0.0973. \\
\hline
\end{tabular}

Signif. codes: “***”: 0-0.001; “.”: 0.05-0.1.

Table A19. $R$ output of ANOVA among the residues generated from the estimation of CFM using species equation and age specific equation for $\mathrm{C} 12$.

\begin{tabular}{lccccc}
\hline \multicolumn{5}{c}{ Analysis of Variance Table } \\
\hline Response: res & Df & Sum Sq & Mean Sq & F Value & Pr $(>\boldsymbol{F})$ \\
\hline trat & 1 & 253.7 & 253.69 & 1.7259 & 0.1921 \\
Residuals & 94 & $13,816.9$ & 146.99 & & \\
\hline
\end{tabular}




\section{Appendix B}

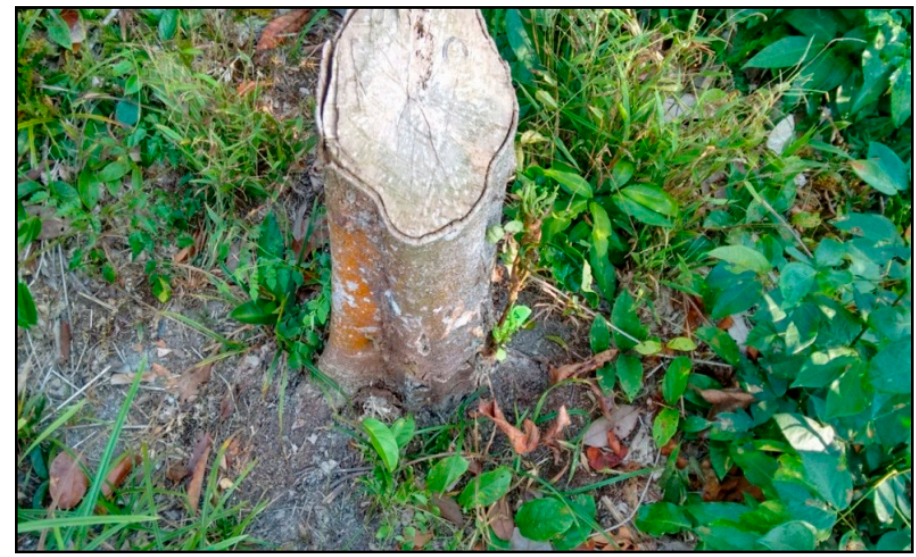

Figure A3. Image of tree cut at $50 \mathrm{~cm}$ from the ground as required by law.

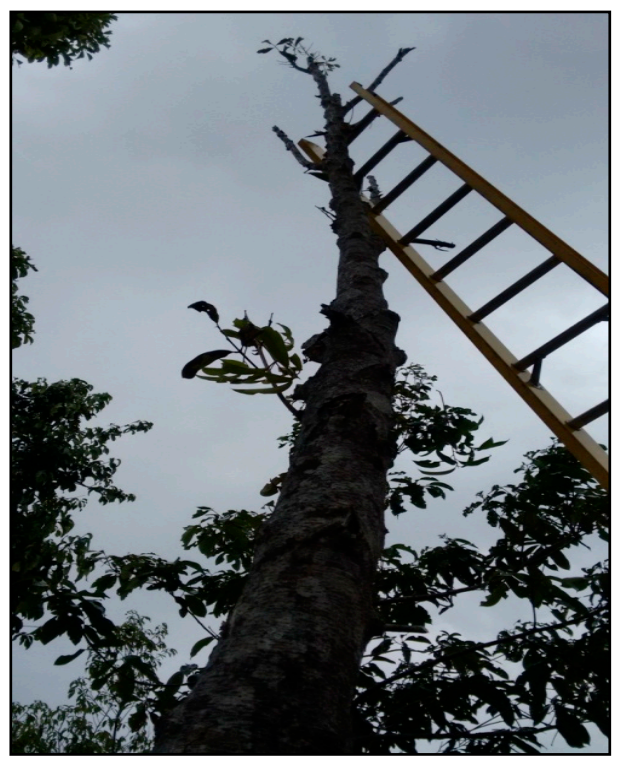

Figure A4. 100\% canopy pruning and canopy climbing ladder for removal of branches and leaves.

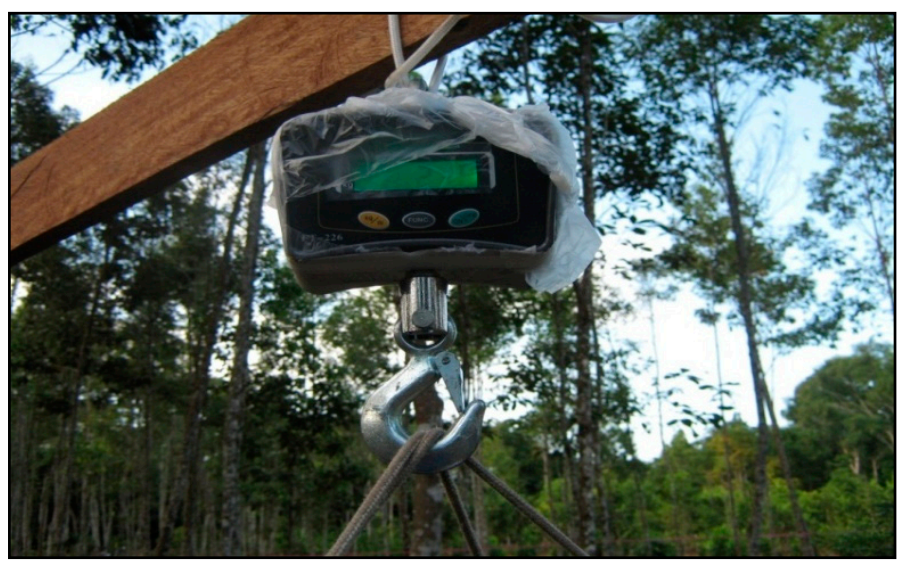

Figure A5. Digital scale for measuring the fresh massof the mass harvested in the rosewood plantations. 

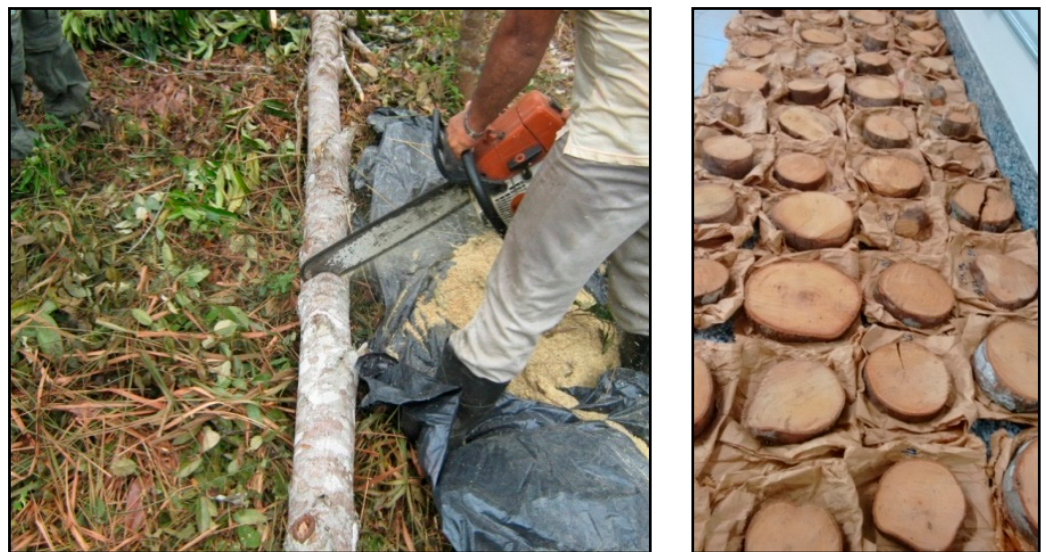

Figure A6. Collecting the wood discs at $0 \%, 50 \%$, and $100 \%$ of the height of the trunk for calculate dry mass; and collecting the sawdust to calculate the mass of the tree.

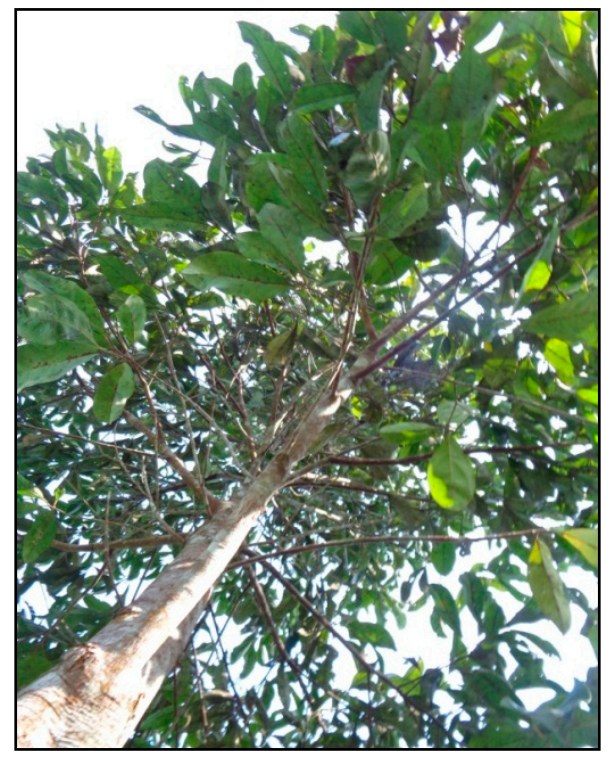

Figure A7. Monopodial growth form with orthotropic main axis.

\section{References}

1. Marques, C.A. A Importância Econômica Da Família Lauraceae Lindl. Floresta e Ambiente 2001, 8, $195-206$.

2. Zanin, S.M.W.; Lordello, A.L.L. Alcalóides aporfinóides do gênero Ocotea (Lauraceae). Química Nova 2007, 30, 92-98. [CrossRef]

3. IBAMA. Instituto Brasileiro do Meio Ambiente e dos Recursos Naturais Renováveis; Portaria 06-N; IBAMA: Recife, Brazil, 1992.

4. CITES. Convention on International Trade in Endangered Species of Wild Fauna and Flora. 2017. Available online: https: / / cites.org/eng/app/appendices.php\#ftnt17 (accessed on 30 August 2017).

5. IUCN. The IUCN Red List of Threatened Species, Version 2014.3. 2014. Available online: http://www. iucnredlist.org (accessed on 11 March 2015).

6. MMA. Ministério do Meio Ambiente; Portaria MMA N 443: Brasília, Brazil, 2014.

7. SDS-Secretaria de Estado do Meio Ambiente e Desenvolvimento Sustentável. Notícias: Semana do Meio. 2006. Available online: http:/ / www.sds.am.gov.br/noticia.php?xcod=2255 (accessed on 1 February 2015).

8. IBAMA. Instituto Brasileiro do Meio Ambiente e dos Recursos Naturais Renováveis; Instrução Normativa IBAMA $\mathrm{N}^{\circ}$ 09: Brasília, Brazil, 2011.

9. Higuchi, N.; dos Santos, J.; Ribeiro, R.J.; Minette, L.; Biot, Y. Biomassa da parte aérea davegetação da floresta tropical úmida de terra-firme da amazonia. Acta Amazon. 1998, 28, 153-166. [CrossRef] 
10. Yuen, J.Q.; Fung, T.; Ziegler, A.D. Review of allometric equations for major land covers in SE Asia: Uncertainty and implications for above-and below-ground carbon estimates. For. Ecol. Manag. 2016, 360, 323-340. [CrossRef]

11. Chave, J.; Réjou-Méchain, M.; Búrquez, A.; Chidumayo, E.; Colgan, M.S.; Delitti, W.B.C.; Duque, A.; Eid, T.; Fearnside, P.M.; Goodman, R.C.; et al. Improved allometric models to estimate the aboveground biomass of tropical trees. Glob. Chang. Biol. 2014, 20, 3177-3190. [CrossRef] [PubMed]

12. Takeda, P.S. Avaliação de Biomassa e óleo da rebrota de Galhos e Folhas de Rosewood (Aniba rosaeodora Ducke) em Plantios Comerciais Submetidos a poda e Adubação. Master's Thesis, Instituto Nacional de Pesquisas da Amazônia/Universidade Federal Rural da Amazônia, Manaus, Brazil, 2008. (In Portuguese)

13. Fidelis, C.H.V.; Augusto, F.; Sampaio, P.T.; Krainovic, P.M.; Barata, L.E. Chemical characterization of rosewood (Aniba rosaeodora Ducke) leaf essential oil by comprehensive two-dimensional gas chromatography coupled with quadrupole mass spectrometry. J. Essent. Oil Res. 2012, 24, 245-251. [CrossRef]

14. Kira, T.; Tsunahide, S. Primary production and turnover of organic matter in different forest ecosystems of the western Pacific. Jpn. J. Ecol. 1967, 17, 70-87. [CrossRef]

15. Basuki, T.M.; Van Laake, P.E.; Skidmore, A.K.; Hussin, Y.A. Allometric equations for estimating the above-ground biomass in tropical lowland Dipterocarp forests. For. Ecol. Manag. 2009, 257, 1684-1694. [CrossRef]

16. Brown, S. Estimating Biomass and Biomass Change of Tropical Forests: A Primer; Food and Agriculture Organization of the United Nations: Rome, Italy, 1997; Volume 134, ISBN 92-5-103955-0.

17. Santos, J. Analize de modelos de regressao para estimar a fitomass de floresta tropical umida de terra-firme de Amazonia Brasiliera. Ph.D. Thesis, Universidade Federal de Vicosa, Minas Gerais, Brazil, 1996. (In Portuguese)

18. Araújo, T.M.; Higuchi, N.; Carvalho, J.A. Comparison of formulae for biomass content determination in a tropical rain forest site in the state of Pará, Brazil. For. Ecol. Manag. 1999, 117, 43-52. [CrossRef]

19. Silva, R.P. Alometria, estoque e dinâmica da biomassa de florestas primárias e secundárias na região de Manaus (AM). Ph.D. Thesis, Universidade Federal do Amazonas, Manaus, Brazil, 2007; p. 152. (In Portuguese with English Abstract)

20. Brown, S.; Gillespie, A.J.R.; Lugo, A.E. Biomass estimation methods for tropical forests with applications to forest inventory data. For. Sci. 1989, 35, 881-902.

21. Brown, S.; Lugo, A.E. Biomass of tropical forests: A new estimate based on forest volumes. Science 1984, 223, 1290-1294. [CrossRef] [PubMed]

22. Fittkau, E.J.; Irmler, U.; Junk, W.J.; Reiss, F.; Schmidt, G.W. Productivity, biomass, and population dynamics in Amazonian water bodies. Trop. Ecol. Syst. 1975, 289-311. [CrossRef]

23. Krainovic, P.M. Plantios de Rosewood (Aniba rosaeodora Ducke) em áreas com histórico de degradação por atividades agrícolas e pecuárias. Master's Thesis, Instituto Nacional de pesquisas da Amazônia, Manaus, Brazil, 2011. (In Portuguese)

24. Kottek, M.; Grieser, J.; Beck, C.; Rudolf, B.; Rubel, F. World map of the Köppen-Geiger climate classification updated. Meteorol. Z. 2006, 15, 259-263. [CrossRef]

25. CLIMATE-DATA.ORG. Climate data for world cities. 2016. Available online: http://en.climate-data.org/ (accessed on 30 August 2017).

26. Tanaka, A.; Vieira, G. Autoecologia das espécies florestais em regime de plantio de enriquecimento em linha na floresta primária da Amazônia Central. Acta Amazon. 2006, 36, 193-204. [CrossRef]

27. Lindell, L.; Åström, M.; Öberg, T. Land-use change versus natural controls on stream water chemistry in the Subandean Amazon, Peru. Appl. Geochem. 2010, 25, 485-495. [CrossRef]

28. Lima, A.J.N. Avaliacão de um Sistema de Inventário Florestal Contínuo em Áreas Manejadas e não Manejadas do Estado do Amazonas (AM). Ph.D. Thesis, Universidade Federal do Amazonas, Manaus, Brazil, 2010; p. 183. (In Portuguese with English Abstract)

29. R Core Team. A Language and Environment for Statistical Computing; R Foundation for Statistical Computing: Vienna, Austria, 2016.

30. Gimenez, B.O.; Danielli, F.E.; De Oliveira, C.K.A.; Dos Santos, J.; Higuchi, N. Volume equations for merchantable timber species of Southern Roraima state I Equações volumétricas para espécies comerciais madeireiras do sul do estado de Roraima. Sci. For. Sci. 2015, 43, 291-301.

31. Husch, B.; Beers, T.W.; Kershaw, J.A., Jr. Forest Mensuration; John Wiley \& Sons: Hoboken, NJ, USA, 2002. 
32. Thant, Y.M.; Kanzaki, M.; Ohta, S.; Than, M.M. Carbon sequestration by mangrove plantations and a natural regeneration stand in the Ayeyarwady Delta, Myanmar. Tropics 2012, 21, 1-10. [CrossRef]

33. Nogueira, E.M.; Fearnside, P.M.; Nelson, B.W.; Barbosa, R.I.; Keizer, E.W.H. Estimates of forest biomass in the Brazilian Amazon: New allometric equations and adjustments to biomass from wood-volume inventories. For. Ecol. Manag. 2008, 256, 1853-1867. [CrossRef]

34. Figueiredo-Filho, A.; Kohler, S.V.; Felde, J.L.; Dias, A.N. Dynamic of stem taper and wood production in Araucaria angustifolia plantations. Cerne 2014, 20, 595-603. [CrossRef]

35. Van de Peer, T.; Verheyen, K.; Kint, V.; Van Cleemput, E.; Muys, B. Plasticity of tree architecture through interspecific and intraspecific competition in a young experimental plantation. For. Ecol. Manag. 2017, 385, 1-9. [CrossRef]

36. Siliprandi, N.C.; Nogueira, E.M.; Toledo, J.J.; Fearnside, P.M.; Nascimento, H.E.M. Inter-site variation in allometry and wood density of Goupia glabra Aubl. in Amazonia. Braz. J. Biol. 2016. [CrossRef] [PubMed]

37. Pretzsch, H. Canopy space filling and tree crown morphology in mixed-species stands compared with monocultures. For. Ecol. Manag. 2014, 327, 251-264. [CrossRef]

38. Peltzer, D.A.; Köchy, M. Competitive effects of grasses and woody plants in mixed-grass prairie. J. Ecol. 2001, 89, 519-527. [CrossRef]

39. Sanderson, M.A.; Elwinger, G.F. Plant density and environment effects on Orchardgrass-White clover mixtures. Crop Sci. 2002, 42, 2055-2063. [CrossRef]

40. Longuetaud, F.; Piboule, A.; Wernsdörfer, H.; Collet, C. Crown plasticity reduces inter-tree competition in a mixed broadleaved forest. Eur. J. For. Res. 2013, 132, 621-634. [CrossRef]

41. Kubitzki, K.; Renner, S. Lauraceae I (Aniba and Aiouea); The New York Botanical Garden: New York, NY, USA, 1982; p. 124.

42. Lorenzi, H. Árvores brasileiras; Nova Odessa: São Paulo, Brazil, 2008.

43. Madriz, R. Campanulaceae. In Nuevo Catálogo de la Flora Vascular de Venezuela; Hokche, O., Berry, P.E., Huber, O., Eds.; Fundación Instituto Botánico de Venezuela: Caracas, Venezuela, 2008; pp. 309-311. (In Spanish)

44. Sampaio, P.T.B.; Barbosa, A.P.; Vieira, G.; Spironello, W.R.; Bruno, F.M.S. Biomassa da rebrota de copas de Rosewood (Aniba rosaeodora Ducke) em plantios sob sombra parcial em floresta primária. Acta Amazon. 2005, 35, 491-494. [CrossRef]

45. Sampaio, P.T.B.; dos Santos, M.C.; Vieira, G.; Spironello, W.; Useche, F.L.; Bruno, F.M.S. Avaliação da rebrota da copa das ávores de pau-rosa (Aniba rosaeodora Ducke) em sistema de podas sucessivas. Acta Amazon. 2007, 37, 55-60. [CrossRef]

46. Alvarez, E.; Duque, A.; Saldarriaga, J.; Cabrera, K.; de Las Salas, G.; del Valle, I.; Rodríguez, L. Tree above-ground biomass allometries for carbon stocks estimation in the natural forests of Colombia. For. Ecol. Manag. 2012, 267, 297-308. [CrossRef]

47. DeMalach, N.; Zaady, E.; Weiner, J.; Kadmon, R. Size asymmetry of resource competition and the structure of plant communities. J. Ecol. 2016. [CrossRef]

48. Tilman, D. Resource Competition and Community Structure; Princeton University Press: Princeton, NJ, USA, 1982.

49. Grime, J.P. Plant Strategies And Vegetation Processes; John Wiley \& Sons: Hoboken, NJ, USA, 1979.

50. Hunter, M.O.; Keller, M.; Victoria, D.; Morton, D.C. Tree height and tropical forest biomass estimation. Biogeosciences 2013, 10, 8385-8399. [CrossRef]

51. Feldpausch, T.H.; Lloyd, J.; Lewis, S.L.; Brienen, R.J.W.; Gloor, M.; Monteagudo Mendoza, A.; Lopez-Gonzalez, G.; Banin, L.; Abu Salim, K.; Affum-Baffoe, K.; et al. Tree height integrated into pantropical forest biomass estimates. Biogeosciences 2012, 9, 3381-3403. [CrossRef]

52. Chave, J.; Andalo, C.; Brown, S.; Cairns, M.A.; Chambers, J.Q.; Eamus, D.; Fölster, H.; Fromard, F.; Higuchi, N.; Kira, T.; et al. Tree allometry and improved estimation of carbon stocks and balance in tropical forests. Oecologia 2005, 145, 87-99. [CrossRef] [PubMed]

53. Hoover, C.M.; Smith, J.E. Evaluating revised biomass equations: are some forest types more equivalent than others? Carbon Balanc. Manag. 2016, 11. [CrossRef] [PubMed]

54. Brasil Projeto Radam Brasil. Levantamento de Recursos Naturais; Ministério das Minas e Energia, Departamento Nacional de Produção Mineral: Rio de Janeiro, Brasil, 1973-1983; pp. 1-23. 
55. Paul, K.I.; Roxburgh, S.H.; England, J.R.; Ritson, P.; Hobbs, T.; Brooksbank, K.; John Raison, R.; Larmour, J.S.; Murphy, S.; Norris, J.; et al. Development and testing of allometric equations for estimating above-ground biomass of mixed-species environmental plantings. For. Ecol. Manag. 2013, 310, 483-494. [CrossRef]

56. Ngomanda, A.; Engone Obiang, N.L.; Lebamba, J.; Moundounga Mavouroulou, Q.; Gomat, H.; Mankou, G.S.; Loumeto, J.; Midoko Iponga, D.; Kossi Ditsouga, F.; Zinga Koumba, R.; et al. Site-specific versus pantropical allometric equations: Which option to estimate the biomass of a moist central African forest? For. Ecol. Manag. 2014, 312, 1-9. [CrossRef]

57. IPCC. Working Group III Contribution to the Intergovernmental Panel on Climate Change Fourth Assessment Report. In Climate Change 2007: Mitigation of Climate Change. Summary for Policymakers; IPCC: Geneva, Switzerland, 2007.

58. Fearnside, P.M. Brazil's Amazon forest in mitigating global warming: Unresolved controversies. Clim. Policy 2012, 12, 70-81. [CrossRef]

59. Fearnside, P.M.; Righi, C.A.; de Alencastro Graça, P.M.L.; Keizer, E.W.; Cerri, C.C.; Nogueira, E.M.; Barbosa, R.I. Biomass and greenhouse-gas emissions from land-use change in Brazil's Amazonian "arc of deforestation": The states of Mato Grosso and Rondônia. For. Ecol. Manag. 2009, 258, 1968-1978. [CrossRef]

(C) 2017 by the authors. Licensee MDPI, Basel, Switzerland. This article is an open access article distributed under the terms and conditions of the Creative Commons Attribution (CC BY) license (http://creativecommons.org/licenses/by/4.0/). 